\title{
Evaluation and Management of Acute Myelopathy
}

\author{
Elia Sechi, MD ${ }^{1}$ Eoin P. Flanagan, MD ${ }^{1,2}$ \\ ${ }^{1}$ Department of Neurology, Mayo Clinic, Rochester, Minnesota \\ 2 Department of Laboratory Medicine and Pathology, Mayo Clinic, \\ Rochester, Minnesota \\ Address for correspondence Eoin P. Flanagan, MD, Department of \\ Neurology and Laboratory Medicine and Pathology, Mayo Clinic, 200 \\ 1st Street SW, Rochester, MN 55905 \\ (e-mail: flanagan.eoin@mayo.edu).
}

Semin Neurol 2021;41:511-529.

\begin{abstract}
Keywords

- spinal cord

- myelitis

- differential diagnosis

- misdiagnosis

- treatment

Acute myelopathies are spinal cord disorders characterized by a rapidly progressive course reaching nadir within hours to a few weeks that may result in severe disability. The multitude of underlying etiologies, complexities in confirming the diagnosis, and often unforgiving nature of spinal cord damage have always represented a challenge. Moreover, certain slowly progressive myelopathies may present acutely or show abrupt worsening in specific settings and thus further complicate the diagnostic workup. Awareness of the clinical and magnetic resonance imaging characteristics of different myelopathies and the specific settings where they occur is fundamental for a correct diagnosis. Neuroimaging helps distinguish compressive etiologies that may require urgent surgery from intrinsic etiologies that generally require medical treatment. Differentiation between various myelopathies is essential to establish timely and appropriate treatment and avoid harm from unnecessary procedures. This article reviews the contemporary spectrum of acute myelopathy etiologies and provides guidance for diagnosis and management.
\end{abstract}

Acute myelopathies are a heterogeneous group of neurologic disorders characterized by rapidly evolving spinal cord dysfunction of multiple etiologies that may result in severe acute and long-term disability. The timing of symptom onset and progression to nadir has important etiological implication, as most myelopathies have a preferential timing of presentation (e.g., inflammatory myelopathies typically present acutely within days, while hereditary myelopathies tend to progress slowly over months). However, certain chronic myelopathies may present acutely or manifest with rapid deterioration in the setting of a previously slowly progressive course. ${ }^{1}$ The severity is mainly dependent on the type (e.g., ischemic vs. inflammatory) and extent (e.g., partial vs. complete) of spinal cord damage. Among inflammatory myelopathies, the myelitis associated with multiple sclerosis (MS) classically affects only part of the spinal cord parenchyma on a transverse section (partial transverse myelitis), while the myelitis associated with autoantibodies against aquaporin-4 (AQP4-IgG) and myelin oligodendrocyte glycoprotein (MOG-IgG) generally results in bilateral/complete transverse spinal cord dysfunction. ${ }^{2}$ The term "idiopathic transverse myelitis (ITM)" defines an acute, bilateral spinal cord dysfunction of unclear etiology that is assumed to be inflammatory. This relies on indirect evidence of spinal cord inflammation and is a common "diagnostic guess" among clinicians when there is uncertainty given the high relative frequency of inflammatory myelopathies in the population and potential for reversibility with immunotherapy. Although diagnostic criteria have been proposed for ITM in $2002,{ }^{3}$ the risk of misdiagnosis is high and noninflammatory myelopathies (e.g., vascular, neoplastic, infectious) can sometimes show laboratory/magnetic resonance imaging (MRI) characteristics typically seen with spinal cord inflammation. ${ }^{4}$ Neuroimaging with MRI is crucial for diagnosis and to help distinguish extrinsic compressive from intrinsic myelopathy etiologies. Differentiation between various myelopathies is fundamental as an incorrect diagnosis may lead to unnecessary procedures (e.g., spinal cord biopsy in patients with severe inflammatory myelopathy misdiagnosed as neoplasm), or
Issue Theme Inpatient Consultations in Neurology; Guest Editors: Pria Anand, $\mathrm{MD}$, and Joshua P. Klein, MD, PhD (c) 2021. Thieme. All rights reserved. Thieme Medical Publishers, Inc., 333 Seventh Avenue, 18th Floor, New York, NY 10001, USA 
inappropriate treatments that may worsen the spinal cord deficit (e.g., corticosteroids in patients with spinal arteriovenous fistulas [AVFs]). In this article, we will review the main causes of acute myelopathy and provide clues for diagnosis and treatment. Traumatic spinal cord injury, the most common cause of spinal cord dysfunction, will be mentioned only briefly, as it is not generally cared for by neurologists in the acute setting; its management is mostly by trauma physicians including orthopaedic surgeons and neurosurgeons. ${ }^{5}$ - Table 1 summarizes the typical demographics, presentation, timing, and clinical/MRI diagnostic clues for myelopathies that can present acutely/subacutely.

\section{Epidemiology}

The epidemiology of myelopathies varies worldwide, and comparison between studies is limited by ethnic and environmental differences that may favor specific etiologies. Traumatic spinal cord injury is the most common cause of acute myelopathy, with an estimated incidence in the United

Table 1 Demographic, clinical, and MRI characteristics of different myelopathy etiologies

\begin{tabular}{|c|c|c|c|}
\hline Myelopathy etiology & Typical onset & Age and sex (if any) & $\begin{array}{l}\text { Clinical, laboratory, and MRI } \\
\text { characteristics }\end{array}$ \\
\hline \multicolumn{4}{|l|}{ Mechanical injury } \\
\hline $\begin{array}{l}\text { Contusion/transaction } \\
\text { (traumatic) })^{5}\end{array}$ & Abrupt & $\begin{array}{l}\text { Bimodal age distribution: } \\
15-30 \text { and }>60 \text { y of age, } \\
80 \% \text { men }\end{array}$ & Recent trauma, vehicle accident \\
\hline $\begin{array}{l}\text { Decompression sickness } \\
\text { (scuba diving } \\
\text { myelopathy) } 45,103,145\end{array}$ & $\begin{array}{l}\text { Acute; possible delayed } \\
\text { onset in a minority of cases }\end{array}$ & Age $40-50 ; 80 \%$ men & $\begin{array}{l}\text { Recent body-decompression } \\
\text { (e.g., diving, flying). MRI: } \\
\text { SCI-like/hemorrhagic changes; } \\
\text { can be normal }\end{array}$ \\
\hline Spondylotic $^{75}$ & $\begin{array}{l}\text { Chronic, a fall/trauma may } \\
\text { lead to acute worsening }\end{array}$ & Age $50-60 ; 70 \%$ men & $\begin{array}{l}\text { Degenerative disc disease. MRI: } \\
\text { long or short T2-lesion at } \\
\text { narrowing level; "pancake" } \\
\text { enhancement; spinal cord } \\
\text { sarcoidosis may coexist }\end{array}$ \\
\hline $\begin{array}{l}\text { Surfer's } \\
\text { myelopathy } 41,146,147\end{array}$ & Hyperacute & Age 20-40; mostly men & $\begin{array}{l}\text { Novice surfer/recent history of } \\
\text { back hyperextension; MRI: similar } \\
\text { to SCI }\end{array}$ \\
\hline \multicolumn{4}{|l|}{ latrogenic } \\
\hline Chemotherapy ${ }^{59,63,148}$ & Variable, can be acute & Variable & $\begin{array}{l}\text { Recent drug exposure: intrathecal } \\
\text { cytarabine, methotrexate, or other } \\
\text { chemotherapies. MRI: tractopathy } \\
\text { (dorsal/lateral column signal } \\
\text { abnormalities), nonspecific or } \\
\text { normal }\end{array}$ \\
\hline $\begin{array}{l}\text { Immune checkpoint } \\
\text { inhibitors }^{62}\end{array}$ & Variable, often acute & $\begin{array}{l}\text { Age } 60-70 \text {; vary with } \\
\text { cancer type }\end{array}$ & $\begin{array}{l}\text { Recent treatment with immune } \\
\text { checkpoint inhibitors; any } \\
\text { immune-mediated myelitis may } \\
\text { potentially occur }\end{array}$ \\
\hline $\begin{array}{l}\text { Post spinal/aortic } \\
\text { surgery } 66\end{array}$ & Hyperacute & Age $60-80$ & $\begin{array}{l}\text { Recent surgery (e.g., spine } \\
\text { degenerative disease, aortic) }\end{array}$ \\
\hline Radiation myelopathy ${ }^{10}$ & $\begin{array}{l}\text { Generally chronic but rapid } \\
\text { deterioration is possible }\end{array}$ & $\begin{array}{l}\text { Age } 30-40 \text {; men more } \\
\text { affected }\end{array}$ & $\begin{array}{l}\text { After spinal cord radiation; } \\
\text { transient Lhermitte's symptom } \\
\text { (>2 mo) or severe myelopathy } \\
\text { (>6 mo). MRI: T2- } \\
\text { hyperintensity } \pm \text { enhancement; } \\
\text { concomitant vertebral body } \\
\text { changes }\end{array}$ \\
\hline TNF- $\alpha$ inhibitors ${ }^{64}$ & Acute & Variable & $\begin{array}{l}\text { MRI: single or multiple nonspecific } \\
\text { CNS demyelinating lesions }\end{array}$ \\
\hline \multicolumn{4}{|c|}{ Inflammatory demyelinating } \\
\hline AQP4-IgG associated 37,83 & Acute & Age 45-55; 90\% women & $\begin{array}{l}\text { Concomitant/preceding ON. MRI: } \\
\text { long T2-lesion “bright spotty } \\
\text { lesions," elongated ring/patchy } \\
\text { enhancement }\end{array}$ \\
\hline
\end{tabular}


Table 1 (Continued)

\begin{tabular}{|c|c|c|c|}
\hline MOG-IgG associated ${ }^{2,21}$ & Acute & Age $10-30$ & $\begin{array}{l}\text { Concomitant/preceding } \\
\text { ON/encephalitis; preceding } \\
\text { infection/vaccination. MRI: } \\
\text { long T2-lesion: "sagittal line" } \\
\text { + "H-sign"; common conus } \\
\text { involvement; initially normal MRI in } \\
10 \%\end{array}$ \\
\hline MS myelitis $^{78}$ & Acute & Age $20-40 ; 70 \%$ women & $\begin{array}{l}\text { Most common myelitis. MRI: } \\
\text { short-peripheral T2-lesions, mostly } \\
\text { on dorsal/lateral columns; } \\
\text { ring/nonspecific enhancement }\end{array}$ \\
\hline \multicolumn{4}{|l|}{ Other immune mediated } \\
\hline $\begin{array}{l}\text { Connective tissue disease } \\
\text { associated (e.g., Behçet’s, } \\
\text { lupus, Sjögren's) }\end{array}$ & Acute & $\begin{array}{l}\text { Age } 30-50 \text {; women more } \\
\text { affected }\end{array}$ & $\begin{array}{l}\text { Systemic/laboratory features of } \\
\text { connective tissue disease. MRI: } \\
\text { "Bagel sign" in Behçet's disease; } \\
\text { SCl-like with vasculitis }\end{array}$ \\
\hline GFAP-IgG associated $^{25,38}$ & $\begin{array}{l}\text { Chronic, acute } \\
\text { presentation is possible }\end{array}$ & Age $40-50$ & $\begin{array}{l}\text { Concomitant } \\
\text { meningoencephalitis, optic disc } \\
\text { edema, and/or tremor; common } \\
\text { viral-like prodrome. MRI: faint long } \\
\text { T2-lesions; } \\
\text { punctate/leptomeningeal } \\
\text { enhancement }\end{array}$ \\
\hline Neurosarcoidosis $^{37,52}$ & $\begin{array}{l}\text { Chronic; acute } \\
\text { presentation in } 20 \% \text { of } \\
\text { cases }\end{array}$ & Age $40-50$ & $\begin{array}{l}\text { Occurs with/without systemic } \\
\text { sarcoid. MRI: long T2-lesion in 50\%; } \\
\text { dorsal subpial enhancement, axial } \\
\text { "trident" sign of enhancement, } \\
\text { persistent enhancement }\end{array}$ \\
\hline Paraneoplastic $^{53}$ & $\begin{array}{l}\text { Chronic; acute } \\
\text { presentation is possible }\end{array}$ & $\begin{array}{l}\text { Age } 60-70 ; \text { slight female } \\
\text { predominance }\end{array}$ & $\begin{array}{l}\text { Known cancer/cancer risk factors } \\
\text { (e.g., smoking); MRI: tract-specific } \\
\text { signal abnormality/enhancement } \\
\text { (dorsal/lateral column); normal } \\
\text { in } 35 \%\end{array}$ \\
\hline \multicolumn{4}{|l|}{ Infectious (see - Table 2) } \\
\hline \multicolumn{4}{|l|}{ Neoplastic } \\
\hline $\begin{array}{l}\text { Primary spinal cord } \\
\text { neoplasms (astrocytoma } \\
\text { and ependymoma account } \\
\text { for } 70 \% \text { of the total) }\end{array}$ & $\begin{array}{l}\text { Chronic; acute onset is } \\
\text { possible with high-grade } \\
\text { tumors/hemorrhage }\end{array}$ & $\begin{array}{l}\text { Age } 30-40 ; 60 \% \text { men; } \\
\text { astrocytoma most } \\
\text { common in children }\end{array}$ & $\begin{array}{l}\text { MRI: expansile mass with cystic } \\
\text { changes and syringomyelia, } \\
\text { cap sign in ependymoma }\end{array}$ \\
\hline $\begin{array}{l}\text { Primary intramedullary } \\
\text { spinal cord lymphoma } 28\end{array}$ & $\begin{array}{l}\text { Chronic; acute onset is } \\
\text { possible }\end{array}$ & Age $60-70 ; 70 \%$ men & $\begin{array}{l}\text { Immunocompromised patients; } \\
\text { MRI: persistent enhancement } \\
\text { (>3 mo) }\end{array}$ \\
\hline $\begin{array}{l}\text { Metastatic disease } \\
\text { (epidural, } \\
\text { intramedullary) }\end{array}$ & $\begin{array}{l}\text { Acute (nadir within } 1 \mathrm{mo} \text { in } \\
75 \% \text { of cases) }\end{array}$ & $\begin{array}{l}\text { Age } 40-65 \text {, slight male } \\
\text { predominance }\end{array}$ & $\begin{array}{l}\text { Epidural enhancing mass; Known } \\
\text { solid-organ cancer (lung and breast } \\
\text { cancer most common); MRI: "rim } \\
\text { and flame" and "central dot" sign }\end{array}$ \\
\hline \multicolumn{4}{|l|}{ Toxic/Metabolic } \\
\hline Biotinidase deficiency $^{58}$ & $\begin{array}{l}\text { Variable, can be } \\
\text { acute/subacute }\end{array}$ & Age $5-20$ & $\begin{array}{l}\text { Vision loss frequently coexists; } \\
\text { lactate elevation in serum and CSF; } \\
\text { MRI: long T2-lesions that can } \\
\text { enhance }\end{array}$ \\
\hline $\begin{array}{l}\text { Vitamin B12, vitamin E, or } \\
\text { copper deficiency } 24,98\end{array}$ & $\begin{array}{l}\text { Chronic; acute } \\
\text { presentation may occur } \\
\text { with } \mathrm{N}_{2} \mathrm{O} \text {, zinc, or inborn } \\
\text { errors of } \mathrm{B} 12 \text { metabolism }\end{array}$ & Age $30-40 ; 67 \%$ men & $\begin{array}{l}\text { Gastric bypass, zinc supplements, } \\
\text { pernicious anemia, malabsorption; } \\
\text { recent anesthetic/ } \mathrm{N}_{2} \mathrm{O} \text { exposure; } \\
\text { MRI: dorsal/lateral column } \\
\text { T2-lesions ("inverted V" sign) }\end{array}$ \\
\hline $\begin{array}{l}\text { Toxic (e.g., cocaine, } \\
\text { heroin) } 40,44\end{array}$ & $\begin{array}{l}\text { Hyperacute with cocaine, } \\
\text { acute with heroin }\end{array}$ & Variable & Recent toxic exposure \\
\hline
\end{tabular}


Table 1 (Continued)

\begin{tabular}{|c|c|c|c|}
\hline $\begin{array}{l}\text { Tropical (e.g., lathyrism, } \\
\text { konzo) } 149,150\end{array}$ & Acute/subacute & Variable & $\begin{array}{l}\text { Malnutrition/ingestion of Cassava } \\
\text { or Lathyrus sativus grass pea in } \\
\text { endemic areas }\end{array}$ \\
\hline \multicolumn{4}{|l|}{ Vascular } \\
\hline Spinal AVF ${ }^{54,92}$ & $\begin{array}{l}\text { Chronic; acute } \\
\text { presentation in } 22 \% \text { of } \\
\text { cases }\end{array}$ & Age $50-70 ; 70 \%$ men & $\begin{array}{l}\text { Clinical worsening after exertion or } \\
\text { steroids. MRI: long thoracic T2- } \\
\text { lesion; perimedullary flow voids, } \\
\text { "missing-piece” sign }\end{array}$ \\
\hline $\begin{array}{l}\text { Other spinal vascular } \\
\text { malformations (e.g., } \\
\text { arteriovenous } \\
\text { malformations, cavernous } \\
\text { malformations) } 151,152\end{array}$ & $\begin{array}{l}\text { Variable based on } \\
\text { malformation type and } \\
\text { spinal location (e.g., } \\
\text { intradural more commonly } \\
\text { acute) }\end{array}$ & $\begin{array}{l}\text { Age } 40-50 \text {; more common } \\
\text { in men }\end{array}$ & $\begin{array}{l}\text { Presentation ranges from acute } \\
\text { bleeding to incidental detection. } \\
\text { MRI: variable; “popcorn" } \\
\text { appearance in cavernous } \\
\text { malformation (heterogenous } \\
\text { intralesional T2-signal due to } \\
\text { multiple microhemorrhages) }\end{array}$ \\
\hline $\begin{array}{l}\text { Spontaneous epidural } \\
\text { hematoma } 153\end{array}$ & Acute & Age $40-50 ; 60 \%$ men & $\begin{array}{l}\text { Bleeding diathesis, trauma, } \\
\text { postsurgical }\end{array}$ \\
\hline Spontaneous SCl${ }^{14}$ & Hyperacute & Age $60-70 ; 60 \%$ men & $\begin{array}{l}\text { Vascular risk factors. MRI: ventral } \\
\text { T2-lesions, "snake/owl eye" sign, } \\
\text { DWI restriction, vertebral body } \\
\text { edge infarction; initially normal } \\
\text { MRI in } 24 \% \text { of cases }\end{array}$ \\
\hline $\begin{array}{l}\text { Fibrocartilaginous } \\
\text { embolism }^{39}\end{array}$ & Hyperacute & $\begin{array}{l}\text { Age } 40-50 ; \text { possible } \\
\text { female predominance }\end{array}$ & $\begin{array}{l}\text { Approximately } 5 \% \text { of spontaneous } \\
\text { SCl; Triggering event often } \\
\text { identifiable (e.g., Valsalva, heavy } \\
\text { lifting); disc adjacent to lesion }\end{array}$ \\
\hline
\end{tabular}

Abbreviations: AQP4, aquaporin-4; AVF, arteriovenous fistula; CNS, central nervous system; CSF, cerebrospinal fluid; MOG, myelin oligodendrocyte glycoprotein; MRI, magnetic resonance imaging; MS, multiple sclerosis; ON, optic neuritis; SCl, spinal cord infarction; TNF, tumor necrosis factor.

States of 40 to 55 cases per million. ${ }^{6,7}$ Inflammatory myelopathies are the second most common cause, but their overall incidence is unknown. One study conducted in New Zealand reported an incidence of acute myelitis of any etiology of 24.6 cases per million, but cases of partial transverse myelitis were excluded. ${ }^{8}$ Among inflammatory myelopathies, MS myelitis represents the most common cause, accounting for approximately one-third of MS cases at onset, ${ }^{9}$ followed by idiopathic myelitis, myelitis associated with specific autoantibodies (e.g., AQP4-IgG, MOG-IgG), spinal cord sarcoidosis, and other less frequent etiologies. In a recent study conducted in Olmsted County (Minnesota), the incidence of ITM by 2002 diagnostic criteria was 8.6 cases per million, while isolated myelitis associated with AQP4-IgG and MOG-IgG had an incidence of approximately 2 cases per million. ${ }^{10} \mathrm{~A}$ similar incidence of 8.8 cases per million is reported for spontaneous epidural abscess. ${ }^{11}$ Robust epidemiological estimates for spinal cord infarction (SCI) are lacking, but in our experience its incidence may approximate that of AQP4-IgG- and MOG-IgG-associated myelitis. The frequency of infectious myelopathies is dependent on the types of infections endemic to each region. Outbreaks of diseases such as enterovirus D68 may occasionally impact the incidence of infectious/parainfectious myelitis worldwide. Certain myelopathies have a predilection for specific age ranges, sex, and ethnicities (e.g., AQP4IgG-associated myelitis is more common among women and Asian or African American patients, while no sex or ethnic predominance is seen with MOG-IgG-associated myelitis), ${ }^{12,13}$ which can provide clues for diagnosis (-Table 1).

\section{Diagnostic Approach}

When faced with convincing clinical symptoms/signs of myelopathy, the first step is gathering a thorough history for possible predisposing factors. For example, a person with a history of metastatic cancer who presents with new symptoms/signs of spinal cord dysfunction is likely to have metastatic compressive myelopathy, while acute onset paraplegia occurring immediately after aortic aneurysm surgery suggests iatrogenic SCI. In addition, a comprehensive assessment of the timing of onset of myelopathy symptoms, imaging, and laboratory findings is crucial. The following stepwise approach may help:

\section{Localization:}

- Do the clinical signs/symptoms localize to the spinal cord?

- If so, is there concomitant evidence of extraspinal neurologic/systemic involvement (e.g., isolated myelopathy vs. encephalomyelopathy/myeloneuropathy)?

\section{Setting:}

- Are there clues in the demographics and history that help narrow the differential diagnosis? 
Table 2 Main causes of intramedullary infection, preferred test, and diagnostic clues ${ }^{26}$

\begin{tabular}{|c|c|c|c|}
\hline Pathogen & $\begin{array}{l}\text { Typical timing of } \\
\text { presentation; at-risk } \\
\text { geographic area (GA), } \\
\text { if any }\end{array}$ & Preferred diagnostic test & Clinical and MRI clues for diagnosis \\
\hline \multicolumn{4}{|l|}{ Bacterial } \\
\hline $\begin{array}{l}\text { Intramedullary abscess } \\
\text { (e.g., Staphylococcus, } \\
\text { Streptococcus, Enterococcus } \\
\text { faecalis, Escherichia coli) }\end{array}$ & Acute & $\begin{array}{l}\text { Blood culture or surgical } \\
\text { drainage cultures (CSF } \\
\text { culture can be negative) }\end{array}$ & $\begin{array}{l}\text { Recent surgical/dental procedure. MRI: } \\
\text { ring enhancement with core DWI } \\
\text { restriction; leptomeningeal } \\
\text { enhancement and/or } \\
\text { spondylo-discitis may coexist }\end{array}$ \\
\hline Borrelia burgdorferi & $\begin{array}{l}\text { Acute; GA: United } \\
\text { States, Europe }\end{array}$ & Serum and CSF serology & $\begin{array}{l}\text { Tick-borne, erythema migrans, } \\
\text { polyarthritis. MRI: nonspecific or } \\
\text { polio-like }\end{array}$ \\
\hline $\begin{array}{l}\text { Mycobacterium } \\
\text { tuberculosis }\end{array}$ & $\begin{array}{l}\text { Chronic; can be } \\
\text { acute/subacute }\end{array}$ & $\begin{array}{l}\text { Mycobacterial culture, CSF } \\
\text { PCR }\end{array}$ & $\begin{array}{l}\text { MRI: leptomeningeal enhancement, } \\
\text { cauda equina, and vertebral body } \\
\text { involvement }\end{array}$ \\
\hline Treponema pallidum $^{155}$ & $\begin{array}{l}\text { Acute; chronic in tabes } \\
\text { dorsalis }\end{array}$ & $\begin{array}{l}\text { Serum rapid plasma reagin, } \\
\text { CSF VDRL }\end{array}$ & $\begin{array}{l}\text { Can manifest as myelitis or spinal cord } \\
\text { infarction (meningovasculitis). MRI: } \\
\text { nonspecific; dorsal column T2- } \\
\text { hyperintensity in tabes dorsalis }\end{array}$ \\
\hline \multicolumn{4}{|l|}{ Viral } \\
\hline Cytomegalovirus & Acute & CSF PCR & $\begin{array}{l}\text { Almost exclusively seen in } \\
\text { immunocompromised patients. MRI: } \\
\text { root/cauda enhancement, normal MRI } \\
\text { in } 50 \%\end{array}$ \\
\hline $\begin{array}{l}\text { Enterovirus (A71, D68, } \\
\text { D70, coxsackie A/B, } \\
\text { echovirus) }\end{array}$ & Acute & CSF PCR & $\begin{array}{l}\text { Common in children or } \\
\text { immunocompromised adults; common } \\
\text { brainstem involvement in acute flaccid } \\
\text { paralysis. MRI: ventral or central gray } \\
\text { matter-restricted; normal in } 5 \% \text { of cases }\end{array}$ \\
\hline Epstein-Barr virus & Acute & $\begin{array}{l}\text { PCR + serology on both } \\
\text { serum and CSF }\end{array}$ & $\begin{array}{l}\text { Preceding/concomitant } \\
\text { mononucleosis. Meningo-encephalo- } \\
\text { radiculitis may coexist. MRI: long } \\
\text { T2-lesion, centrally } \\
\text { located } \pm \text { enhancement }\end{array}$ \\
\hline Herpes simplex virus $1 / 2^{95}$ & Acute & CSF PCR & $\begin{array}{l}\text { Myelitis, radiculitis, or both } \\
\text { (myeloradiculitis), common lumbosacral } \\
\text { involvement (Elsberg's syndrome [HSV-2 } \\
\text { accompanied by genital herpes]). MRI: } \\
\text { multiple, discontinued, central/ventral } \\
\text { lesions sparing the distal conus; nerve } \\
\text { root enhancement }\end{array}$ \\
\hline HIV & Acute/Chronic & CSF PCR, serology & $\begin{array}{l}\text { May occur acutely during } \\
\text { seroconversion or chronically in } \\
\text { advanced AIDS, other opportunistic } \\
\text { causes need to be excluded. MRI: } \\
\text { non-enhancing } \\
\text { T2-lesions along the dorsal columns }\end{array}$ \\
\hline Human herpesvirus 6/7 & Acute & CSF PCR & $\begin{array}{l}\text { May occur in transplanted patients; } \\
\text { generalized pruritus may coexist. }\end{array}$ \\
\hline JC virus ${ }^{156}$ & Acute & CSF PCR & $\begin{array}{l}\text { Only few cases of spinal cord } \\
\text { involvement reported in } \\
\text { immunocompromised patients }\end{array}$ \\
\hline Poliovirus & $\begin{array}{l}\text { Acute; GA: Some African } \\
\text { countries }\end{array}$ & CSF serology, stool culture & $\begin{array}{l}\text { May occur in underdeveloped countries } \\
\text { where the vaccine is not available; } \\
\text { acute flaccid myelitis, } \\
\text { bulbar/autonomic dysfunction may } \\
\text { occur. MRI: ventral or central gray } \\
\text { matter involvement }\end{array}$ \\
\hline
\end{tabular}


Table 2 (Continued)

\begin{tabular}{|c|c|c|c|}
\hline Pathogen & $\begin{array}{l}\text { Typical timing of } \\
\text { presentation; at-risk } \\
\text { geographic area (GA), } \\
\text { if any }\end{array}$ & Preferred diagnostic test & Clinical and MRI clues for diagnosis \\
\hline Rabies & Acute & CSF and blood serology & $\begin{array}{l}\text { Recent animal bite/contact; severe } \\
\text { course. MRI: long T2-lesion, central } \\
\text { cord restricted }\end{array}$ \\
\hline Varicella zoster virus ${ }^{97}$ & Acute & CSF serology $>$ PCR & $\begin{array}{l}\text { The myelitis can occur with/without } \\
\text { rash. MRI: dorsal or gray matter } \\
\text { restricted T2-lesions (single or multiple, } \\
\text { long or short) at the level of the } \\
\text { affected ganglion, enhancement is } \\
\text { possible }\end{array}$ \\
\hline West Nile virus & Acute & $\begin{array}{l}\text { CSF PCR, serology on both } \\
\text { serum and CSF }\end{array}$ & $\begin{array}{l}\text { Myelitis in } 5-10 \% \text { of neurological cases; } \\
\text { acute flaccid paralysis, } \\
\text { meningoencephalitis may coexist. MRI: } \\
\text { predominant ventral cord involvement, } \\
\text { can be normal }\end{array}$ \\
\hline Zika virus & $\begin{array}{l}\text { Acute; GA: Central } \\
\text { South America, Asia, } \\
\text { Africa }\end{array}$ & CSF PCR & $\begin{array}{l}\text { Guillain-Barre syndrome or acute } \\
\text { myelitis has been reported. MRI is } \\
\text { nonspecific }\end{array}$ \\
\hline \multicolumn{4}{|l|}{ Parasitical/fungal } \\
\hline $\begin{array}{l}\text { Cryptococcus (neoformans/ } \\
\text { gattii) and other } \\
\text { fungi } 157,158\end{array}$ & Chronic & $\begin{array}{l}\text { CSF and blood serology, } \\
\text { CSF antigen, India ink } \\
\text { staining }\end{array}$ & $\begin{array}{l}\text { Cryptococcus, Candida, Aspergillus, and } \\
\text { Zygomycetes are common; } \\
\text { meningoencephalitis most common } \\
\text { manifestation }\end{array}$ \\
\hline $\begin{array}{l}\text { Taenia solium } \\
\text { (neurocysticercosis) }\end{array}$ & $\begin{array}{l}\text { Chronic; GA: America, } \\
\text { Central South Asia, } \\
\text { Africa, Eastern Europe }\end{array}$ & CSF and blood serology & $\begin{array}{l}\text { Spinal cord involvement is rare } \\
\text { compared with brain involvement, MRI: } \\
\text { intraspinal cord or leptomeningeal } \\
\text { enhancing cysts with cystic content } \\
\text { (T2-signal isointense to the surrounding } \\
\text { CSF) }\end{array}$ \\
\hline $\begin{array}{l}\text { Schistosoma mansonil } \\
\text { haematobium }\end{array}$ & $\begin{array}{l}\text { Acute; GA: South } \\
\text { America, Middle East, } \\
\text { Africa, Asia }\end{array}$ & $\begin{array}{l}\text { Histopathology, serology, } \\
\text { stool culture }\end{array}$ & $\begin{array}{l}\text { Recent swimming in fresh water; } \\
\text { myelitis or myeloradiculitis. MRI: } \\
\text { multinodular enhancement mass in the } \\
\text { lower thoracic cord }\end{array}$ \\
\hline Toxoplasma gondii & Acute & $\begin{array}{l}\text { Serology and PCR in both } \\
\text { CSF and blood }\end{array}$ & $\begin{array}{l}\text { Raw/undercooked meat ingestion; MRI: } \\
\text { nonspecific enhancing, expansile mass }\end{array}$ \\
\hline
\end{tabular}

Abbreviations: AIDS, acquired immunodeficiency syndrome; CSF, cerebrospinal fluid; DWI, diffusion-weighted image; GA, geographic area; HIV, human immunodeficiency virus; MRI, magnetic resonance imaging; PCR, polymerase chain reaction.

\section{Timing:}

- Is the clinical presentation hyperacute ( $<12$ hours), acute/subacute ( 1-21 days), or acute-on-chronic (over weeks/months)?

4. Spine imaging:

- Does MRI confirm the spinal cord involvement?

- Are there signs of extrinsic compression?

- Is the intrinsic spinal cord lesion longitudinally extensive ( $\geq 3$ vertebral segments)?

- Is there any recognizable sign or gadolinium enhancement pattern that can suggest a specific etiology?

5. Additional tests:

- Is the brain MRI abnormal?

- Do other investigations provide a clue (e.g., blood/ cerebrospinal fluid [CSF] findings)?

\section{Clinical Manifestations}

Myelopathies can manifest with different combinations of signs/symptoms of motor, sensory, or autonomic dysfunction affecting one or more limbs and trunk (face-sparing), with predominant involvement of certain functional systems being sometimes suggestive of specific etiologies.

The motor weakness is typically accompanied by spasticity and hyperreflexia with Hoffman or Babinski's signs below the level of the lesion. Weakness generally follows an upper motor neuron pattern distribution with more severe involvement of flexor muscles in the lower limbs and extensor muscles in the upper limbs. A severe motor impairment requiring gait aid is unusual in MS but common with other acute myelitis etiologies (e.g., AQP4-IgG/MOG-IgG associated). ${ }^{2}$ Anterior spinal artery infarction is characterized by hyperacute onset of bilateral and severe weakness with 
sparing of the dorsal columns, although this clinical pattern is not always present and sensory disturbances can appear after the first hours/days due to expanding edema surrounding the ischemic area. ${ }^{14}$ MS myelitis is characterized by mild, sensory-predominant deficits that resolve spontaneously over days or weeks. Reduced or absent reflexes can be seen after abrupt severe spinal cord insults (spinal shock), with extensive involvement of the anterior horns (common with SCI and viral myelitis), ${ }^{14,15}$ or with concomitant peripheral neuropathy. ${ }^{16}$ Acute compression of the cauda equina below the L1-L2 level (cauda equina syndrome) is characterized by flaccid paraparesis/plegia, loss of sensation below the groin/saddle region, and early incontinence that may resemble spinal shock, although spinal shock is often accompanied by spinal cord abnormalities on MRI. ${ }^{17}$

Sensory disturbances may vary from positive (e.g., burning/itchy sensation) to negative (e.g., hypo-/anesthesia) manifestations that are often nonspecific and difficult to distinguish from those of peripheral neuropathies. Predominant involvement of pain and temperature with relative sparing of vibration sense and proprioception can be seen with predominant central cord damage (e.g., syringomyelia). ${ }^{17}$ When present, a sensory level on the trunk (reported by the patient or detected on examination) or a Lhermitte phenomenon (i.e., an electrical sensation along the back sometimes extending to the extremities triggered by neck flexion) is highly suggestive of a spinal cord localization, and the latter is most suggestive of a demyelinating etiology. An intense back pain heralding myelopathy symptom onset is also common with acute myelopathies. ${ }^{14}$ Dysmetria predominantly affecting the lower limbs may occur due to damage of the spinocerebellar tracts. ${ }^{18}$ Tonic spasms (i.e., paroxysmal, unilateral, stereotyped episodes of painful tonic posturing of the limbs of 1-3 minutes of duration, triggered by movement, and typically responsive to low-dose carbamazepine) are commonly seen with inflammatory/demyelinating myelopathies, especially AQP4-IgG associated. ${ }^{19}$ The McArdle sign (a rapidly reversible weakness induced by neck flexion) is characteristic of MS. ${ }^{20}$

Bladder dysfunction (incontinence or retention) is common, but is nonspecific when it occurs in isolation. Neurogenic bowel may manifest as constipation or fecal incontinence. Erectile dysfunction is a common accompaniment in males. Cardiovascular and other autonomic instability and respiratory failure can be seen with upper cervical cord involvement.

Acute inflammatory demyelinating polyneuropathy may sometimes mimic acute myelopathies, particularly those with a flaccid paraparesis from spinal shock, or myelopathies that can initially present without findings on MRI. ${ }^{21}$ The presence of a sensory level on the trunk, an upper motor neuron pattern of weakness on examination, and urinary retention (more than incontinence) favors a myelopathy over a peripheral nervous system disorder.

Demonstrating signs/symptoms of extraspinal neurologic involvement is helpful to narrow the differential. The concomitance of peripheral neuropathy and myelopathy (myeloneuropathy) can be seen with some inflammatory etiologies, ${ }^{22,23}$ but is more common in inherited ${ }^{18}$ and nutritional myelopathies. ${ }^{24}$ Encephalopathy/cognitive impairment or seizures are common with glial fibrillary acidic protein (GFAP)-IgG, ${ }^{25}$ inherited/nutritional disorders, ${ }^{18}$ certain infections, ${ }^{26}$ neurosarcoidosis, ${ }^{27}$ dual spinal cord and cerebral involvement of lymphoma, ${ }^{28}$ and less frequently AQP4-IgG. ${ }^{29}$ Acute disseminated encephalomyelitis (ADEM) is a clinicoradiologic phenotype characterized by encephalopathy and multifocal central nervous system (CNS) demyelination frequently seen with MOG-IgG. ${ }^{30}$ Patients with MS myelitis may have focal brain symptoms but rarely encephalopathy. Optic neuritis can be seen with AQP4-IgG and MOG-IgG (typically bilateral and/or severe) and MS myelitis (typically unilateral and less severe). Intractable nausea, vomiting, or hiccups due to involvement of area postrema are seen with AQP4-IgG, ${ }^{31}$ while meningitis can be seen with MOG-IgG, GFAP-IgG, sarcoidosis, or infections. Optic disc edema (often asymptomatic) and tremor are common with GFAP-IgG. ${ }^{25}$

Systemic manifestations accompanying the myelopathy are common with infections or rheumatologic disorders that can affect the spinal cord. It is important to enquire about a history of oral/genital ulcers (Behçet's disease), ${ }^{32}$ dry eyes/mouth (Sjögren's disease), ${ }^{33}$ or skin rash (e.g., malar rash in systemic lupus erythematosus), ${ }^{34}$ while the presence of skin ulcers, purpura, or other cutaneous lesions suggest vasculitis, ${ }^{35}$ infections, $^{36}$ or sarcoidosis. ${ }^{37}$ Viral-like prodromes (e.g., fever, weight loss) preceding the myelopathy are common with rheumatologic disorders and infections, but can also be seen with MOG-IgG, ${ }^{2}$ GFAP-IgG, ${ }^{38}$ or neoplasms.

\section{Presentation Timing and Setting}

In acute myelopathies, patients are generally able to identify the exact day of symptom onset, while more vague descriptions are often reported by patients with chronic or subacute myelopathies.

\section{Hyperacute Onset}

A hyperacute onset within 12 hours is characteristic of spontaneous SCI, although symptom progression more than 12 hours is seen in approximately $25 \%$ of cases, typically in a stuttering/stepwise fashion. ${ }^{14}$ In a minority of patients with spontaneous SCI (especially young patients), a triggering event can be identified, including (1) Valsalva maneuver, heavy lifting, or a new/intense physical activity suggestive of fibrocartilaginous embolism ${ }^{39}$; (2) cocaine use ${ }^{40}$; or (3) rapid back hyperextension (typical of novice surfers). ${ }^{41} \mathrm{SCI}$ can also be caused by vasculitis in the context of systemic rheumatologic disorders (e.g., ANCA associated, lupus, giant cell arteritis), ${ }^{35,42,43}$ prothrombotic disorders (antiphospholipid syndrome), or infections (e.g., syphilitic or varicella zoster virus vasculopathy). ${ }^{26} \mathrm{~A}$ hyperacute presentation may also occur with heroin exposure, particularly with heroin reuse after a period of abstinence, ${ }^{44}$ rapid body decompression among scuba divers, ${ }^{45}$ and spinal hemorrhage. Nontraumatic intramedullary hemorrhages (hematomyelia) are generally secondary to vascular malformations (cavernous 
malformations, arteriovascular malformations, high-flow AVFs), neoplasms (primary or metastases), anticoagulation treatment, or hereditary bleeding disorders. ${ }^{46}$ Similar causes can be identified in patients with spontaneous spinal epidural hematoma, which can also occur after spine surgery, although the majority of cases are idiopathic. ${ }^{47}$ AQP4-IgGand MOG-IgG-associated myelitis may sometimes reach maximal severity within 12 to 24 hours, but rarely in a sudden, "stroke-like" fashion.

\section{Acute to Subacute Onset}

Most inflammatory myelopathies present within days to a few weeks (acute/subacute presentation; - Table 1), with MS myelitis being the most common. Major red flags that suggest a non-MS myelitis are (1) a longitudinally extensive lesion on spinal cord MRI and (2) a particularly severe disabling myelopathy. ${ }^{2}$ The myelitis associated with AQP4IgG and MOG-IgG is almost always acute/subacute, ${ }^{2}$ along with most idiopathic myelitis. ${ }^{10}$ Infectious myelitis frequently presents acutely and should be particularly suspected in immunosuppressed patients, intravenous drug users, or patients with a recent history of travel to at-risk areas, although certain pathogens are typically associated with a slowly progressive course such as HTLV-1. ${ }^{26}$ - Table 2 summarizes the major causes of acute infectious myelitis and their characteristics. Acute necrotizing myelopathy is characterized by intralesional necrosis, hemorrhage, and cavitation generally occurring after viral infections, including most recently SARS-CoV-2. ${ }^{48}$ A characteristic syndrome of acute flaccid myelopathy and sometimes cranial nerve dysfunction has been reported in association with viral infections by poliovirus, enterovirus D68, D70, A71, coxsackievirus A and $B$, and echovirus. ${ }^{15}$ West Nile virus myelitis can present similarly. A specific association between a predominantly sensory acute myelopathy with noninflammatory CSF and elevated serum IgE levels directed against mite antigens (atopic myelitis) has also been described, predominantly in Asia. ${ }^{49}$ Spinal cord metastases typically have an acute presentation, while primary spinal cord tumors may sometimes present acutely when high grade or in the setting of an accompanying hemorrhage, but generally have a subacute to chronic course. Myelopathies due to toxic agents or drugs typically present acutely/hyperacutely in close temporal relation to the exposure. Spinal cord compression from extrinsic causes (e.g., epidural hematoma/abscess, vertebral disk herniation) can also manifest acutely.

\section{Acute-on-Chronic Onset}

Among the chronic myelopathies, spondylotic myelopathy is the most common, and an acute worsening may occur after trauma or vertebral disk herniation. ${ }^{50,51}$ Other chronic myelopathies have an acute presentation in a minority of cases, including spinal cord sarcoidosis (acute presentation in $20 \%),{ }^{52}$ paraneoplastic myelopathies, ${ }^{53}$ and spinal AVF (acute presentation in 22\%). ${ }^{54}$ Subacute combined degeneration is a typically chronic myelopathy, but acute presentations have been reported. ${ }^{55}$ An acute onset is also seen with rapid B12 inactivation from nitrous oxide intoxication ${ }^{24,56}$ or in patients with an underlying inborn error of cobalamin metabolism/adsorption (often with normal serum B12 levels). ${ }^{57}$ Biotinidase deficiency may mimic neuromyelitis optica. ${ }^{58}$ Hereditary myelopathies and progressive MS typically present insidiously over months to years.

\section{latrogenic Etiologies}

Myelopathy occurring with a cancer history may suggest spinal cord metastasis, a paraneoplastic etiology, or an iatrogenic cause such as intrathecal cytarabine or methotrexate toxicity or radiation myelopathy. ${ }^{59}$ Radiation myelopathy is a rare complication of radiation exposure to the spinal cord, typically for the treatment of spinal or abdominal/thoracic malignancies. A mild radiation myelopathy characterized by Lhermitte phenomenon and spontaneous resolution may develop 2 to 4 months after the exposure, while a more severe, frequently irreversible form may present from 6 months to years after treatment. ${ }^{60}$ In patients with a history of spine radiation, the diagnosis relies on the exclusion of other possible etiologies, especially cancer recurrence. ${ }^{61}$ Cancer treatment with immune checkpoint inhibitors may trigger neurologic immune-mediated disorders, including myelitis, ${ }^{62}$ while tumor necrosis factor (TNF)- $\alpha$ inhibitors may trigger CNS demyelinating lesions in the brain and/or the spinal cord. ${ }^{63,64}$ Neurological autoimmunity has also been described in patients receiving immunosuppression following organ transplantation. ${ }^{65}$ Other common iatrogenic causes include spine surgery, anesthesia, and aortic surgery, which may lead to SCI in up to $1 \%$ of cases. ${ }^{66,67}$ Spinal cord involvement has also been reported in cases of posterior reversible encephalopathy syndrome, ${ }^{68}$ sometimes associated with AQP4-IgG. ${ }^{69}$

\section{Spine Imaging}

Spinal cord MRI is the gold standard to confirm the clinical suspicion of myelopathy, although certain myelopathies may manifest clinically but without associated findings on initial MRI. ${ }^{21}$ An optimal imaging protocol for acute myelopathy should include both sagittal and axial T2-weighted sequences, short-tau inversion recovery (STIR) sequences, pre- and postgadolinium T1-weighted sequences, and sagittal diffusion-weighted images (DWIs) with apparent diffusion coefficient (ADC) maps. Postgadolinium images are particularly important, as they may reveal specific enhancement patterns. ${ }^{70}$ Computed tomography (CT) is often preferred to MRI acutely in the setting of trauma due to its greater sensitivity for detecting vertebral fractures and blood. ${ }^{71}$ CT and CTmyelography can complement MRI in case of structural spine disorders or in patients with contraindications to MRI. ${ }^{72}$

\section{Extrinsic Causes of Myelopathy}

MRI should first exclude extrinsic causes of acute spinal cord compression that may require surgical intervention. In general, acute spinal cord compression may be due to bony structures (e.g., spondylosis, trauma, fractures), intervertebral disk disorders (e.g., disk herniation, calcification, cysts), or masses that can originate in or invade the epidural, subdural, or 
subarachnoid space. ${ }^{73}$ The epidural space is rich in venous plexuses and fat that predispose to abscesses, metastases, or hematomas that can then compress the spinal cord. ${ }^{1}$

Imaging of the entire spine is important to detect compression at multiple levels or distant spinal cord abnormalities. At the level of the compression, the spinal cord can be normal or show parenchymal T2 abnormalities. MRI characteristics of common compressive masses include the following:

- Epidural abscess/hematoma-A longitudinally extensive collection of T2-hyperintense/T1-hypo- or isointense fluid in the dorsal or ventral epidural space is typical (-Fig. 1A). A rim of gadolinium enhancement around the epidural mass is frequent with epidural abscess and may extend to the leptomeninges. Adjacent vertebral osteomyelitis with T1-hypointensity and loss of cortical bone margins and/or T2-hyperintensity of the intervertebral disk indicating discitis are also common (e.g., Pott disease in tuberculous infection), although epidural abscesses may occur in isolation from direct hematogenous dissemination. ${ }^{1,73}$ Epidural and subdural spinal hematomas typically lack gadolinium enhancement. ${ }^{71}$

- Neoplastic mass-The MRI characteristics vary with the tumor type, but gadolinium enhancement is generally more homogeneous than epidural abscess and not confined to the margins of the mass. Concomitant vertebral metastases are common. In patients with multiple myeloma, spinal cord compression is generally due to vertebral collapse, while lymphomas commonly grow in the epidural space on either side of the spinal cord ( $\mathbf{F i g . ~ 1 B )})^{74}$

- Spondylotic myelopathy -A flat, intramedullary, transverse band of contrast enhancement just below the level of maximal stenosis on sagittal images ("pancake" enhancement), which involves the white matter and spares the central gray matter axially, is characteristic. ${ }^{75} \mathrm{~A}$ rapid worsening in these patients can be seen after a trauma or acute disc extrusion (-Fig. 1C). When cervical spondylotic myelopathy is not overt, dynamic spinal cord MRI with flexion and extension views may help confirm the diagnosis. ${ }^{76}$

\section{Intrinsic Causes of Myelopathy}

Once compressive insults have reasonably been ruled out, assessing the length of the spinal cord lesion on sagittal T2weighted images (the longest if multiple lesions are present) further assists the diagnostic workup. Short T2-hyperintense lesions $(<3$ contiguous vertebral segments on sagittal images), particularly when multiple, are typical of MS. The lesions are generally peripherally located in the dorsal or

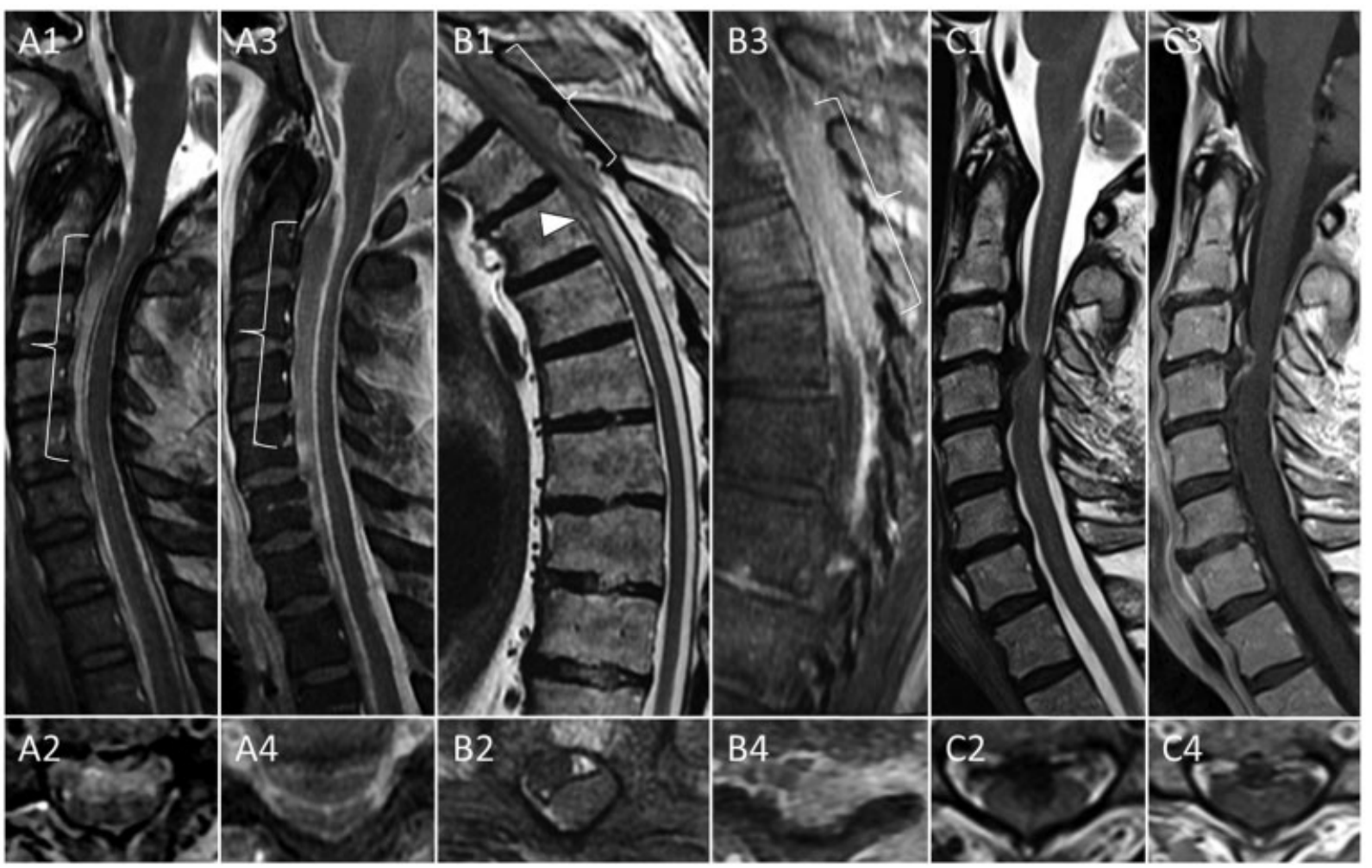

Fig. 1 Examples of compressive myelopathies. (A) Epidural abscess. A T2-hyperintense fluid collection in the anterior epidural space compressing the cervical spinal cord is appreciable on both sagittal (A1) and axial (A2) images. Enhancement of the abscess margins and leptomeninges is shown with extensive purulence of CSF noted on fat-saturated T1-weighted images after gadolinium (A3-A4). (B) Diffuse large B-cell lymphoma. A mildly T2-hyperintense mass compressing the thoracic spinal cord from the dorsolateral epidural space and accompanying increased T2-signal of the adjacent spinal cord parenchyma (arrow) is noted (B1-B2). The neoplastic mass shows intense gadolinium enhancement (B3-B4). (C) Spondylotic myelopathy. Anterior compression of the cervical spinal cord from intervertebral disk extrusion is shown. The hypointense extruded disk on T2-weighted images $(C 1-C 2)$ is surrounded by a thin rim of enhancement at the level of the compression on postgadolinium images (C3-C4). 


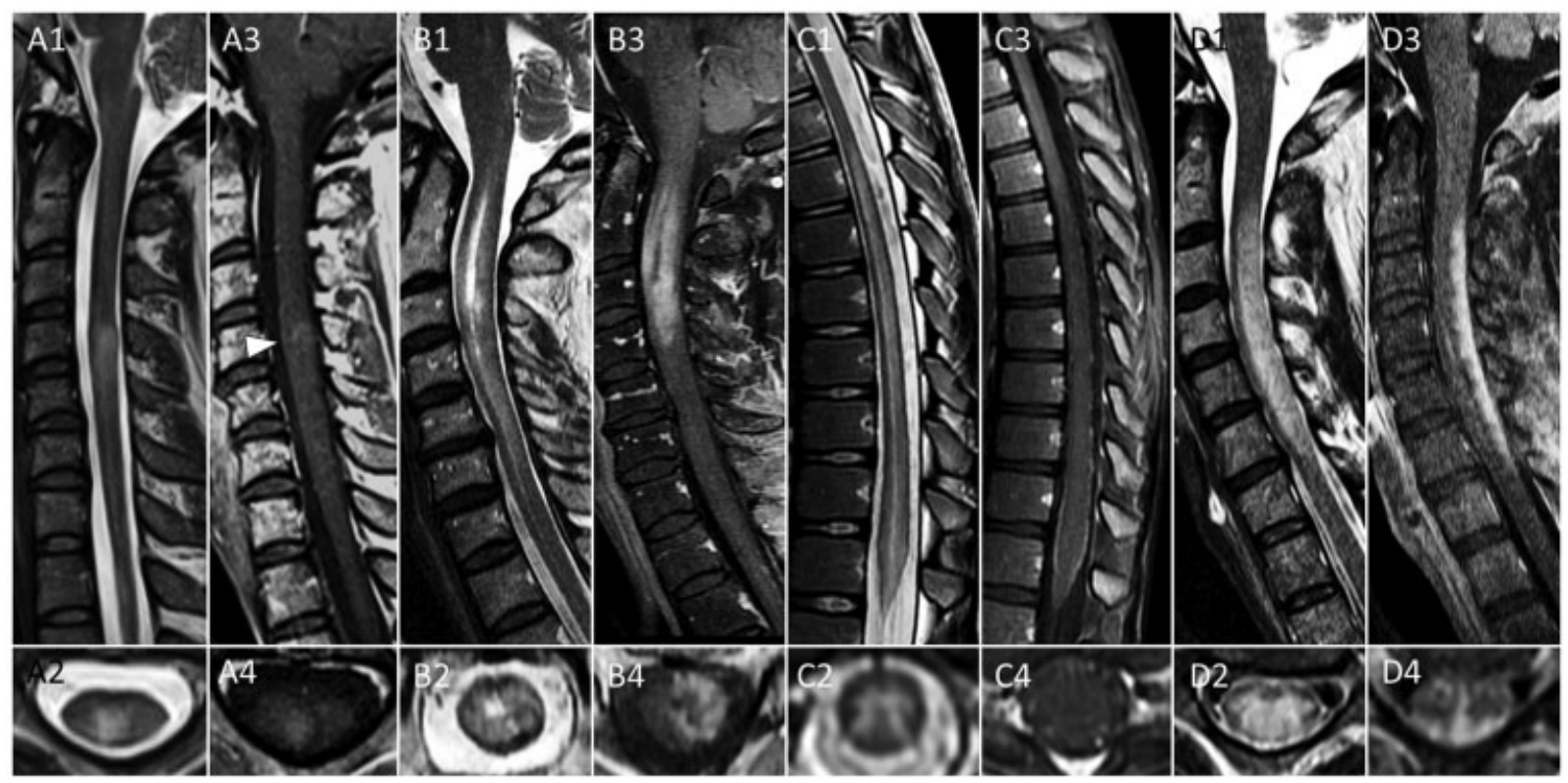

Fig. 2 Examples of inflammatory myelopathies. (A) Multiple sclerosis. A short ( $<3$ contiguous vertebral body segments) T2-hyperintense lesion along the dorsal columns is noted on sagittal (A1) and axial images (A2), with corresponding nonspecific enhancement after gadolinium (A3A4). (B) AQP4-IgG-associated myelitis. A longitudinally extensive ( $\geq 3$ contiguous vertebral body segments) T2-lesion with associated swelling of the cervical spinal cord, and a focal area of higher T2-hyperintensity within the lesion ("bright spotty lesion") visible on both sagittal (B1) and axial (B2) images. After gadolinium there is marked enhancement of the periphery of the lesion (B3-B4). (C) MOG-IgG-associated myelitis. A longitudinally extensive T2-lesion involving the entirety of the thoracic spinal cord, more pronounced ventrally on sagittal images (C1) and gray matter-restricted axially (C2). No enhancement is noted after gadolinium (C3-C4). (D) Spinal cord sarcoidosis. A longitudinally extensive cervical T2-lesion (D1-D2) is noted with associated gadolinium enhancement along the dorsal subpial surface (D3), and anterior extension to the central canal resembling a trident ("trident sign") on axial images (D4).

lateral columns, and are often accompanied by either homogeneous or rim enhancement if acute (-Fig. 2A). Long T2hyperintense lesions ( $\geq 3$ contiguous vertebral body segments) are rarely seen in $\mathrm{MS},{ }^{77}$ but are common with AQP4-IgG and MOG-IgG. ${ }^{78}$ Rarely, multiple contiguous MS lesions may resemble a single longitudinally extensive lesion on sagittal images; in these patients, a careful evaluation of axial images helps demonstrate the presence of multifocal T2 abnormalities. ${ }^{77}$ Linear dorsal column T2-lesions, with or without enhancement, can also be seen in patients with sensory ganglionopathy associated with specific paraneoplastic autoantibodies (e.g., antineuronal nuclear antibody1), ${ }^{79}$ connective tissue disorders (e.g., Sjögren's disease), ${ }^{80}$ amyloidosis, and exposure to certain drugs (e.g., cisplatin).

Among intrinsic causes of myelopathy that commonly manifest with longitudinally extensive spinal cord lesions, several may show characteristic MRI signs and/or enhancement patterns:

- AQP4-IgG associated-Marked swelling and central/ holocord involvement on axial images are common, ${ }^{81}$ with intralesional foci of higher T2-hyperintensity similar to the surrounding CSF ("bright spotty lesions") ${ }^{82}$; gadolinium enhancement is present in more than $90 \%$ of cases acutely and can be patchy or ring-like ("elongated ring"; -Fig. 2B). ${ }^{83}$ Short myelitis T2-lesions are seen in $14 \%$ of cases, ${ }^{84}$ and involvement of the conus is infrequent. ${ }^{2}$

- MOG-IgG associated-The T2 hyperintensity is frequently more pronounced along the ventral cord parenchyma on sagittal images ("ventral sagittal line") and gray matter restricted on axial images ("H-sign") ${ }^{2}$; conus involvement is common (-Fig. 2C). ${ }^{85}$ Gadolinium enhancement is observed in approximately $50 \%$ of cases acutely and is usually faint and nonspecific; long and short myelitis lesions frequently coexist ${ }^{2}$; the initial MRI can be negative in $10 \%$ despite a severe myelitis. ${ }^{21}$

- GFAP-IgG associated-A faint, poorly demarcated T2-lesion, extending over the entire cord, occurs most frequently. ${ }^{38}$ Punctate parenchymal enhancement, enhancement of the central canal, and/or leptomeningeal enhancement are common. This myelitis rarely occurs without concomitant clinical/MRI evidence of extraspinal neurologic involvement. ${ }^{38}$

- Spinal cord sarcoidosis-A very bright subpial enhancement is typical along the dorsal cord surface, ${ }^{37}$ sometimes extending to the central canal and resembling a trident on axial images ("trident sign"; -Fig. 2D) ${ }^{86}$; concomitant leptomeningeal/radicular involvement is common. Predominantly anterior abnormalities may be seen in association with spondylosis. Persistence of gadolinium enhancement over 6 months is characteristic. Nonlongitudinally extensive lesions or isolated meningoradiculitis are seen in $50 \%$ of cases. ${ }^{52}$

- Behçet's myelitis-Focal areas of T2-hypointensity are frequently noted within the lesions, with or without accompanying enhancement, and often resembling a bagel on axial images ("bagel sign"). It has a predilection for the midthoracic region. ${ }^{32}$ 
- Spinal cord infarct-The ventral spinal cord T2-hyperintensity is typically affected in a sagittal "pencil-like" or axial "owl/snake eyes" pattern with involvement of the anterior horn cells, which are the most vulnerable region of the spinal cord to ischemia and are often injured in a watershed pattern. Abnormal gadolinium enhancement may appear a few days after symptom onset in $39 \%$ of cases (-Fig. 3A). An accompanying parenchymal DWI restriction is useful to assess for, but this imaging technique is limited by poor spatial resolution and artifacts when compared with analogous brain sequences. T2-/T1post-gadolinium hyperintensity of the dorsal edge of an adjacent vertebral body (due to concomitant vertebral body infarct) can also be noted in the days to weeks following the infarct. ${ }^{14,87}$ Dorsal cord infarction is possible and more commonly manifests with short nonspecific dorsal column lesions accompanied by an acute sensory ataxia. ${ }^{14}$ The initial MRI in SCI is negative in $24 \%$ within the first 24 hours. ${ }^{14}$ Lesion evolution to myelomalacia is common, and a small punched out T2-hyperintensity with T1-hypointensity of similar constituency to CSF may be encountered in the cord parenchyma in follow-up.

- Hematomyelia-The MRI signal of blood is heterogeneous and varies over days from the initial bleeding. The detection of precontrast T1-hyperintensity on MRI suggests the presence of blood in the subacute phase of a hemorrhage ( -Fig. 3B), although it can also be seen with lipid content (e.g., lipoma), or melanoma metastasis (due to the paramagnetic properties of melanin). ${ }^{88,89}$

- Spinal AVF-Typically affects the lower half of the thoracic spinal cord, although the cervical spinal cord can be affected sometimes with an intracranial location of the fistula. ${ }^{90}$ Paraspinal flow voids from venous congestion are often dorsal and are pathognomonic, but may be absent or subtle and difficult to appreciate in up to $50 \%$ of cases. Thus, any longitudinally extensive T2-hyperintense lesion in the thoracic spine should lead to strong consideration for a dural AVF. Gadolinium enhancement is common (up to $86 \%$ of cases) and may lead to misdiagnosis as an inflammatory/neoplastic etiology. ${ }^{54,91}$ Occasionally, the MRI will reveal a focal nonenhancing area of spinal cord parenchyma within a region of diffuse enhancement ("missing piece sign"; - Fig. 3C). ${ }^{92}$

- Primary spinal cord tumors-Intramedullary cystic T2hyperintense lesions and syringohydromyelia are common with all tumor types, although some tumors have longitudinally extensive lesions isointense to the spinal cord parenchyma. Ependymomas are more often located centrally, and astrocytomas often have a more peripheral location, although there is some overlap. Gadolinium enhancement is observed in the majority of cases (-Fig. 4A). A T2-hypointense "cap" of hemosiderin due to previous hemorrhages above and/or below the expansile T2-mass ("cap sign") is seen in one-third of

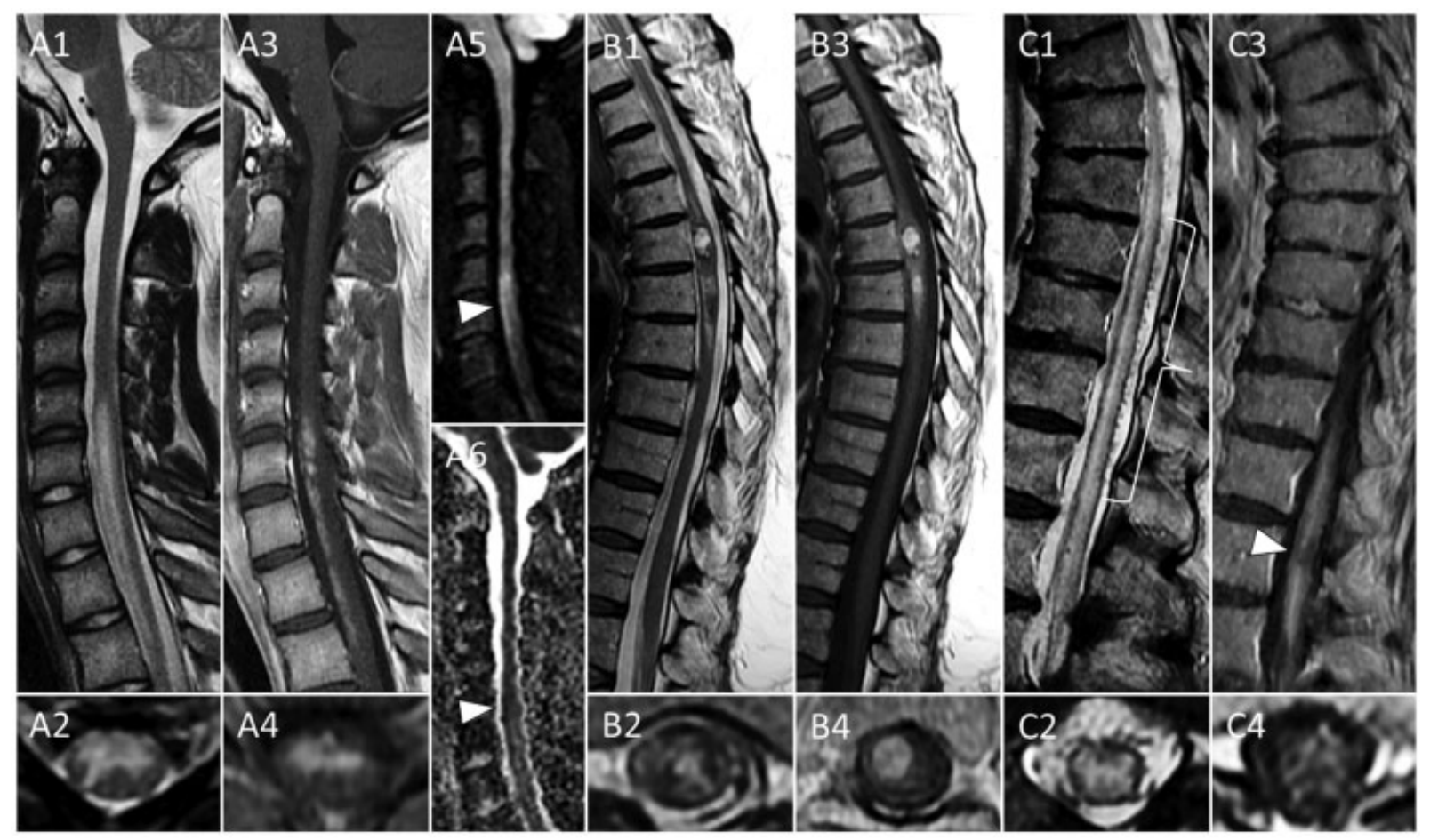

Fig. 3 Examples of vascular myelopathies. (A) Spinal cord infarction. A longitudinally extensive T2-lesion is noted along the anterior two-thirds of the lower cervical and upper thoracic spinal cord on both sagittal (A1) and axial (A2) images, with corresponding enhancement after gadolinium (A3-A4). On diffusion-weighted images, the ischemic lesion shows restricted diffusion (A5) and corresponding hypointensity on apparent diffusion coefficient map (A6). (B) Hematomyelia. In a case of intraparenchymal bleeding, the T2-lesion signal often appears heterogeneous due to the concomitant presence of blood products of different ages (B1-B2). On pregadolinium T1-weighted images of the blood often appears hyperintense (B3-B4). (C) Spinal dural arteriovenous fistula. The longitudinally extensive T2-lesion involving the distal thoracic spinal cord is accompanied by multiple dorsal hypointense areas (flow voids) from venous congestion (C1-C2). After gadolinium, the diffuse lesion enhancement is interrupted by a focal nonenhancing area ("missing piece sign"; arrowhead) of spinal cord parenchyma (C3-C4). 


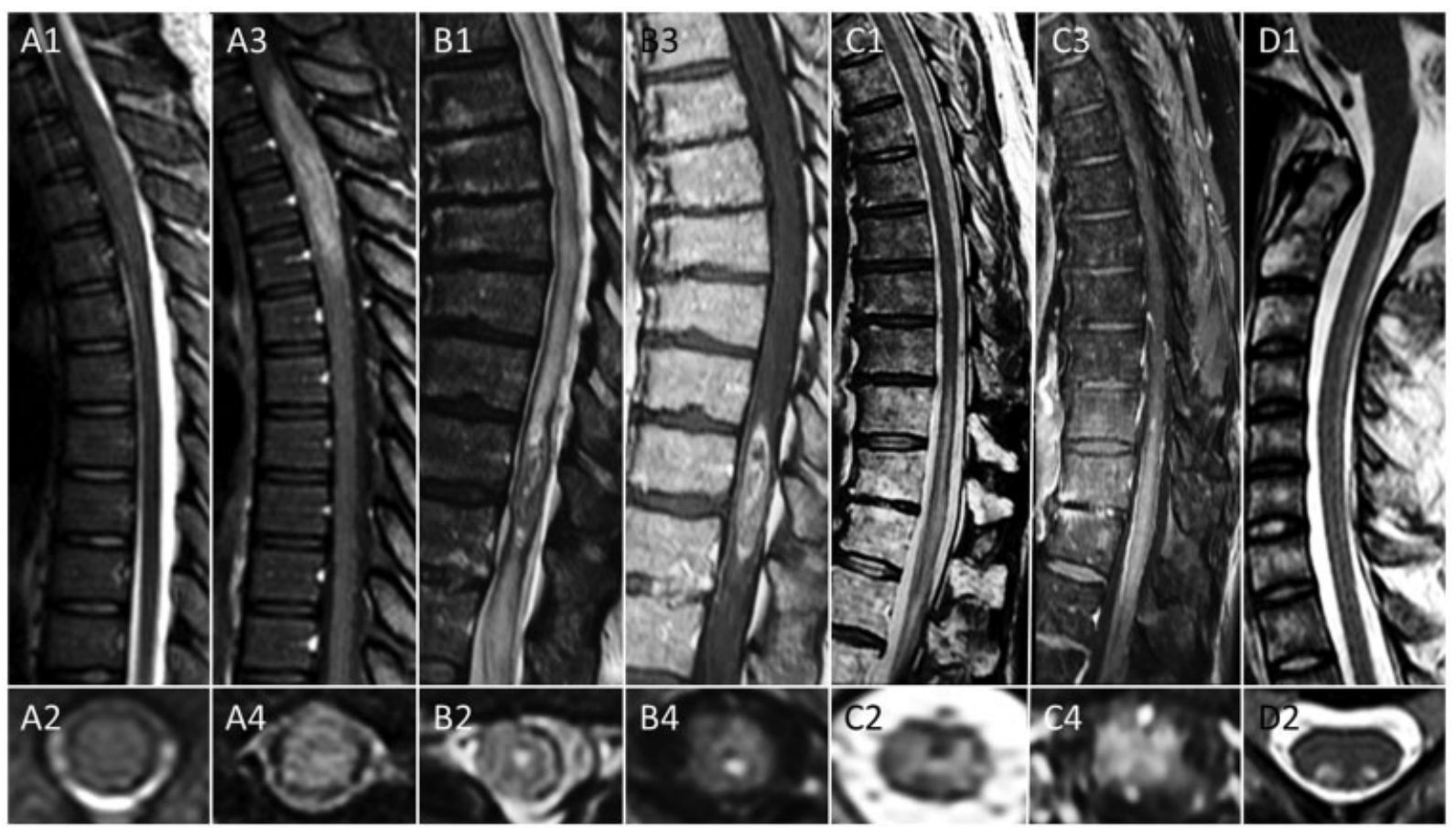

Fig. 4 Examples of other intrinsic causes of myelopathy. (A) High-grade spinal cord astrocytoma. A longitudinally extensive iso- to hyperintense lesion is evident in the upper thoracic spinal cord on T2-weighted images (A1-A2). Diffuse, nonspecific lesion enhancement is noted after gadolinium (A3-A4). (B) Spinal cord intramedullary metastasis. A highly heterogeneous T2-lesion is evident in the lower thoracic spinal cord (B1), with irregular, mostly peripheral enhancement after gadolinium (B3). A focal dotty area of hyperintense signal in the center of the spinal cord is evident on both T2-weighted (B2) and postgadolinium T1-weighted (B4) sequences axially ("central dot sign"). (C) West Nile virus myelitis. A longitudinally extensive T2-hyperintense lesion, predominantly affecting the central gray matter, is evident in the lower third of the thoracic spinal cord (C1-C2). Diffuse, nonspecific enhancement is noted after gadolinium in the affected spinal cord parenchyma and adjacent leptomeninges (C3-C4). (D) Myelopathy from intrathecal methotrexate infusion. A longitudinally extensive T2-hyperintensity is evident along the dorsal columns in the cervical and upper thoracic spinal cord on both sagittal (D1) and axial (D2) images. The lesion does not enhance after gadolinium (not shown).

ependymomas and other highly vascularized tumors. ${ }^{74}$ Initial improvement with steroids and persistence of gadolinium enhancement over months is suggestive of spinal cord lymphoma. ${ }^{28}$ The contrast enhancement patterns differ based on the tumor type (e.g., homogeneous enhancement in ependymoma, patchy enhancement in spinal cord astrocytoma). ${ }^{74}$

- Intramedullary spinal cord metastasis-The "rim" (i.e., a more intense thin rim of peripheral enhancement surrounding an enhancing lesion) and "flame" (i.e., an illdefined flame-shaped region of enhancement at the superior or inferior lesion margin) sign, and the "central dot" sign (i.e., a singular intense, punctate focus of enhancement in/near the center of a less intensely enhancing intramedullary lesion) are characteristic and favor spinal cord metastasis over primary neoplasias or other etiologies (- Fig. 4B) ${ }^{93,94}$

- Infectious myelitis-MRI findings differ based on the specific pathogen (-Table 2). Most viral myelitides (e.g., West Nile, poliovirus) are characterized by predominant involvement of the ventral or central gray matter, sometimes accompanied by nonspecific gadolinium enhancement (-Fig. 4C). Elsberg syndrome is a lumbosacral radiculitis often accompanied by lower cord myelitis that may occur during or after HSV-2 infection. Multiple and discontinuous T2-hyperintensities in the conus medullaris that can enhance after gadolinium are often detected.$^{95}$ Varicella zoster virus myelitis typically affects the central gray matter or the dorsal columns, with single or multiple, long or short T2-hyperintense lesions at the level of the skin rash (when present). ${ }^{96,97}$

Patients with vitamin B12, vitamin E, or copper deficiency may show short or longitudinally extensive T2-hyperintensity along the dorsal and/or lateral columns ("inverted V" sign), with or without associated enhancement. ${ }^{98-100}$ Resolution of MRI abnormalities with vitamin supplementation may precede clinical improvement. ${ }^{101}$ Cognitive symptoms or optic neuropathy may coexist. ${ }^{98} \mathrm{~A}$ tract-restricted T2-hyperintensity along the dorsal or lateral columns can also be observed in paraneoplastic myelopathies with corresponding tract-specific enhancement, and after intrathecal administration of certain chemotherapies (- Fig. 4D). For other longitudinally extensive myelopathies (e.g., myelitis associated with connective tissue disorders, radiation myelopathy, ${ }^{102}$ genetic/inherited myelopathies, ${ }^{18}$ surfer's/scuba diving myelopathy, ${ }^{103}$ ITM), MRI findings are more nonspecific.

\section{Laboratory Investigations}

Serum and CSF analysis may reveal infections, inflammatory markers, or specific autoantibodies associated with 
neurologic or systemic autoimmunity. When possible, samples should be collected acutely and before treatment to limit confounders (e.g., detection of antibodies will be limited after a course of plasma exchange [PLEX]). An optimal serum investigation panel for acute myelopathy includes complete blood cell count, liver and kidney function tests, erythrocyte sedimentation rate, C-reactive protein, antinuclear and extractable nuclear antigens, antineutrophil cytoplasmic antibodies, and specific nutrients/vitamins (B12, E, and copper). Increased serum white blood cell count, C-reactive protein, and erythrocyte sedimentation rate suggest infectious or systemic inflammatory disorders. Serum protein electrophoresis, immunofixation, and lactate dehydrogenase may help detect hematologic malignancies, while coagulation tests are important to rule out coagulopathies or a bleeding diathesis. More specific testing (e.g., biotinidase, long chain fatty acid, genetic testing) can be considered in selected cases.

For infectious etiologies, the optimal test varies based on the specific pathogen (-Table 2). Polymerase chain reaction (PCR) in CSF is generally the gold standard for viral infections, with exceptions like varicella zoster virus, for which serology yields higher sensitivity. ${ }^{104}$ PCR may be negative early in the disease course. Testing both serum and CSF is recommended, especially for infections that begin systemically (e.g., Epstein-Barr virus, Borrelia burgdorferi), as an isolated CSF positivity with negative serum test should raise the suspicion of a false-positive result. Serology may be negative in immunocompromised patients or after B-cell-depleting agents (e.g., rituximab, ocrelizumab). ${ }^{105}$

In patients with epidural abscess, cultures may be unrevealing if preceded by empiric antibiotics. Serial blood cultures at admission increase the likelihood of identifying a pathogen. The most commonly identified organisms worldwide are Staphylococcus aureus and streptococcus, while Pseudomonas is common among intravenous drug users. Mycobacterium tuberculosis is frequent in endemic areas. $^{36}$

CSF pleocytosis ( $>5$ white blood cells per $\mathrm{mm}^{3}$ ) and/or high IgG index are regarded as indicators of CSF inflammation, but they are not specific and mild elevations in CSF white blood cell count can be sometimes seen with noninflammatory myelopathies (e.g., vascular myelopathies). ${ }^{106}$ Lymphocyte predominance is typically seen with inflammatory, viral, fungal, and TB etiologies, while polymorphonuclear cells predominate with bacterial infections, some viral infections (e.g., West Nile), and Behçet's disease, or early during an inflammatory myelitis. ${ }^{107}$ Eosinophils and monocytes can be seen with parasitic and fungal infections, respectively. ${ }^{26}$ In MS, the white blood cell count does not generally exceed 50 cells, and higher values should prompt consideration of other etiologies. CSF-restricted oligoclonal bands are typical with MS (present in 85-100\%) and certain viral infections, ${ }^{108}$ less common with sarcoidosis and GFAPIgG (30-50\%), ${ }^{38,52}$ and uncommon with AQP4/MOG-IgG (15-20\%), where they can be transiently detected during relapses. ${ }^{2}$ Low CSF glucose $(<40 \mathrm{mg} / \mathrm{dL})$ suggests meningomyelitis with infections, neoplasms, or chronic inflammation (e.g., sarcoidosis). ${ }^{109}$ Elevated CSF protein $(>45 \mathrm{mg} / \mathrm{dL})$ can be seen with obstruction of CSF flow, ${ }^{110}$ while a high opening pressure is expected with bacterial/fungal infections. ${ }^{26}$ CSF cytology and flow cytometry are useful to identify neoplastic cells.

Testing for specific autoantibodies associated with myelitis may confirm an autoimmune or paraneoplastic etiology. While serum testing is generally preferred for AQP4-IgG and MOG-IgG because of increased sensitivity, ${ }^{111,112}$ isolated CSF MOG-IgG positivity has been reported on rare occasions. ${ }^{113}$ GFAP-IgG is preferentially tested in CSF. $^{25}$ In patients with paraneoplastic myelopathies, antibodies against amphiphysin and collapsing response mediator protein-5 (anti-CRMP5/anti-CV2), which are generally detectable in both serum and CSF, are the most common, although seronegative forms are possible. ${ }^{53}$ When the suspicion is high, immunofluorescence or immunohistochemistry screening on mouse brain tissue on both serum and CSF in dedicated research laboratories can help identify unexpected or yet unclassified neural-specific autoantibodies.

\section{Additional Investigations}

Brain MRI abnormalities accompanying the myelopathy (either symptomatic or not) are common with MS myelitis (small juxtacortical, periventricular, or infratentorial ovoidshaped lesions), ${ }^{78}$ ADEM/MOG-IgG (large poorly defined "fluffy" lesions), ${ }^{114}$ GFAP-IgG (radially oriented linear perivascular enhancement-"radial enhancement"), ${ }^{38}$ sometimes AQP4-IgG (peri-third/fourth ventricles or large tumefactive white matter lesions), ${ }^{29}$ and neurosarcoidosis (e.g., bright homogeneous subpial/basilar leptomeningeal enhancement). ${ }^{27}$

Whole-body CT scan can demonstrate systemic inflammatory foci for biopsy in patients with sarcoidosis or metastatic spinal cord lesion. ${ }^{18} \mathrm{~F}$-fluorodeoxyglucose positron emission tomography (FDG-PET) has a greater sensitivity and is helpful to demonstrate occult systemic involvement in patients with neurosarcoidosis or systemic malignancy. ${ }^{115}$ In patients with active myelopathy, the detection of hypermetabolic activity in the spinal cord lesion favors neurosarcoidosis or spinal cord tumors versus other etiologies. ${ }^{116}$ Focal FDG-uptake may be seen with acute/subacute disk herniation or Schmorl nodes associated with an inflammatory response and can mimic metastatic disease. ${ }^{73}$ When paraneoplastic autoantibodies with strong cancer association are detected without known malignancies, a periodic cancer screening (every 6-12 months) is recommended, as paraneoplastic manifestations may precede cancer detection by months or years. ${ }^{117}$ Cancer screening should include FDGPET of the torso, mammography, and other specific investigations, as appropriate. ${ }^{118}$ Electromyography study can demonstrate a myeloneuropathy or a pure peripheral deficit mimicking a myelopathy (e.g., cauda equina syndrome, Guillain-Barré syndrome). Somatosensory evoked potentials can confirm spinal cord dysfunction when the MRI is normal. ${ }^{21}$ Traditional spinal angiography is the gold standard for the detection of vascular malformations, although MRI angiography is also accurate and can help localize the 
malformation and guide formal angiography. ${ }^{119}$ The sensitivity of angiography for AVF detection is operator-dependent and increases with repeated exams and experienced operators. ${ }^{120}$ Spinal cord biopsy can be considered when clinical deficits are severe and diagnosis is uncertain and can be safely undertaken in specialized centers with low complication rates. $^{121}$

\section{Treatment and Management}

The management of acute myelopathies encompasses (1) an initial general risk assessment, (2) identification of those who may need surgical intervention, and (3) treatment of the specific etiology.

\section{General Risk Assessment}

Patients with clinical and/or MRI evidence of high cervical spinal cord or bulbar involvement should be assessed for the risk of respiratory failure and hemodynamic instability, starting with physical examination maneuvers to detect early respiratory distress signs (e.g., the presence of paradoxical breathing, inability/difficulty to count out loud from 1 to 20 in a single breath). ${ }^{122}$ Neurogenic shock may occur with severe acute neurologic damage from traumatic or nontraumatic myelopathies, and is characterized by systemic hypotension from sudden loss of sympathetic stimulation to the blood vessels below the level of the lesion, sometimes accompanied by reduced heart rate from unopposed vagal activity.

Baseline investigations should include electrocardiography, blood pressure, oxygen saturation, and arterial blood gas. The presence of hypoxic respiratory failure should prompt consideration of mechanical ventilation, while systolic hypotension $(\leq 90 \mathrm{~mm} \mathrm{Hg})$ and/or reduced heart rate $(\leq 40)$ should prompt hemodynamic stabilization with supportive fluids, inotropes, and vasoactive agents. ${ }^{122}$ In cases of clinical/MRI evidence of severe spinal cord damage above the C5 level and normal baseline parameters, intensive care unit (ICU) monitoring for the first 24 to 36 hours can be considered. ${ }^{122} \mathrm{~A}$ bedside swallow assessment is recommended with bulbar symptoms/signs, while an indwelling bladder catheter is often needed with severe myelopathies.

\section{Surgical Indications}

Acute nontraumatic myelopathies that may require surgical intervention include extrinsic compressive myelopathies of all causes or infarction due to aortic dissection. Compression from spinal epidural abscesses is a medical emergency generally treated with spinal decompression and drainage in combination with broad-spectrum antibiotic coverage while awaiting microbial cultures. Early surgical decompression is also the treatment of choice with epidural hematomas. Anticoagulants or antiplatelet agents should be discontinued or reversed as applicable. ${ }^{123}$ In patients with spinal cord compression due to epidural metastases, dexamethasone (from 16 to $96 \mathrm{mg} /$ day) in combination with surgery, radiation, or both can be considered and may depend on the radiosensitivity of the tumor and the patient's functional status. Most patients with spondylotic myelopathy stabilize with or without improvement after decompressive surgery. The residual T2-hyperintensity may persist, and gadolinium enhancement, when present, tends to resolve quite slowly ( $>6$ months), which may lead to diagnostic confusion. ${ }^{75}$

Surgical ligation or endovascular embolization is indicated for spinal AVF and may be considered in other vascular malformations, but up to $13 \%$ of cases require further interventions due to incomplete treatment or fistula recurrence, particularly with embolization. ${ }^{54}$ In patients with SCI of any type (iatrogenic or spontaneous), increasing parenchymal perfusion through collateral vessels by blood pressure augmentation and lumbar drainage remain of potential benefit in the absence of randomized controlled trials. ${ }^{124} \mathrm{~A}$ spontaneous functional recovery occurs in about one-third of patients with SCI. ${ }^{125}$

\section{Acute Pharmacological Treatment}

Once infectious myelitis and spinal AVF have reasonably been ruled out, an empiric immunotherapy trial may be reasonable in uncertain severe cases given the high frequency of inflammatory myelopathies. An immunotherapy trial may be both therapeutic and diagnostic in case of response (although a transient initial response may also be seen with lymphoma). ${ }^{28}$ One or more of the following treatments are generally considered:

- High-dose intravenous methylprednisolone (IVMP), 1 g/day $\times 3-5$ days.

- PLEX, 1 exchange every other day for five to seven exchanges.

Intravenous immunoglobulins (IVIG: $0.4 \mathrm{~g} / \mathrm{kg} / \mathrm{day} \times 5$ days, then weekly for 6-12 weeks) can also be considered, especially in children. A similar approach is generally appropriate for every type of myelitis, including ITM. Corticosteroids are generally preferred given the easier accessibility and lower risk profile, although lack of response does not exclude an inflammatory etiology. In particular, steroids alone are often ineffective with AQP4IgG-associated myelitis, where complete recovery is seen in only one-third of patients. ${ }^{126}$ Early use of PLEX/ immunoadsorption (alone or with corticosteroids) is recommended with AQP4-IgG, ${ }^{127}$ with maximum improvement within 5 days from symptoms onset. ${ }^{128}$ PLEX was proven to be effective for the treatment of severe demyelinating attacks of different etiologies in a randomized sham-controlled trial. ${ }^{129}$ IVIG can also be considered as an alternative to PLEX. ${ }^{130}$ The optimal treatment of MOGIgG-associated myelitis is unknown, but most patients show complete or nearly complete recovery despite severe attacks, unlike AQP4-IgG-associated relapses, for which recovery is less complete. ${ }^{2,131}$ In patients with MS myelitis, a single IVMP course of 3 to 5 days is usually sufficient, given the milder disability and that complete or nearly complete recovery is typical. Administration of an equivalent oral dose of methylprednisolone has been shown to be similarly effective and safe at 1 month. ${ }^{132}$ 
The specific treatment of infectious myelitis depends on the underlying pathogen, and with viral myelitis may vary from antiviral treatment (when available) to supportive therapy. Complete details of the treatments for infectious myelopathies are beyond the scope of this article and have been reviewed elsewhere. ${ }^{26}$

In patients with high suspicion for spontaneous $\mathrm{SCI}$, empiric thrombolysis can be considered within the first few hours from onset and in the absence of major contraindications. ${ }^{133}$ For drug-related myelitis, treatment withdrawal should be evaluated, with additional immunotherapy for the immune-mediated forms (e.g., TNF- $\alpha$ /immune checkpoint inhibitor-related). In patients with cancer who develop immune-mediated complications from checkpoint inhibitors, the risk/benefit of drug withdrawal should be carefully weighed. Improvement has been reported with corticosteroids alone while maintaining the immune checkpoint inhibitor in patients with mild-moderate forms. $^{62}$

\section{Maintenance Treatment}

Long-term immunotherapy is particularly important in patients with myelitis that is prone to a relapsing course, especially AQP4-IgG/MOG-IgG-associated disorders and MS. Other disorders like sarcoidosis and Behçet's may also relapse or follow a steroid-dependent course.

In patients with AQP4-IgG-associated myelitis, several drugs have recently been proven effective for relapse prevention in phase 3 prospective randomized placebo-controlled clinical trials, including rituximab (anti-CD20 ${ }^{+}$ lymphocytes), ${ }^{134}$ inebilizumab (anti-CD19 ${ }^{+}$lymphocytes), ${ }^{135}$ eculizumab (anti-C5 complement protein), ${ }^{136}$ and satralizumab (anti-interleukin 6). ${ }^{137}$ In patients with MOG-IgG-associated myelitis, the decision to begin longterm immunotherapy is often challenging, as up to $50 \%$ will be monophasic and thus not need immunotherapy. A slow steroid taper after the acute stage for a few months may reduce the risk of early relapse. ${ }^{138}$ Furthermore, the longterm outcome in these patients is generally favorable with just mild to moderate residual disability despite a highly relapsing course. ${ }^{139}$ Empiric attack-prevention immunosuppression is often utilized in relapsing disease, but randomized-controlled trials are lacking. Treatment options include mycophenolate mofetil, ${ }^{140}$ azathioprine, ${ }^{141}$ periodic IVIG, ${ }^{141}$ and rituximab, although rituximab seems less effective than in AQP4-IgG-associated myelitis. ${ }^{142}$ Prolonged high-dose oral steroids are utilized for spinal cord sarcoidosis, with $1 \mathrm{mg} / \mathrm{kg} \times 3$ months followed by a slow taper over the next 6 to 12 months, and can also be used with GFAP-IgG. ${ }^{37,38}$ TNF- $\alpha$ inhibitors are an effective option for both sarcoidosis and Behçet's disease. Several disease-modifying agents are available for MS relapse prevention. ${ }^{143}$

In patients with spontaneous $\mathrm{SCI}$, a thorough cardiovascular risk assessment is important to evaluate for the cause, and antiplatelet or anticoagulation therapy may be considered in addition to managing other risk factors. In patients with neurological complications from immune checkpoint inhibitors that improve after drug withdrawal, there is currently no evidence to support long-term immunosup- pression, although relapse may occur. ${ }^{62}$ Therapy rechallenge with the same or a different immune checkpoint inhibitor is not recommended in patients with moderate-severe neurological manifestations unless strictly necessary for cancer treatment. $^{144}$

\section{Conclusions}

Acute myelopathies are crucial for neurologists to diagnose, as disability can accrue rapidly and irreversibly without treatment. Identifying extrinsic compressive myelopathies with the help of neuroimaging is the first step, as extramedullary etiologies often require early surgical intervention. For intramedullary myelopathies, advances in autoantibody biomarker discovery and identification of MRI patterns have allowed earlier and more accurate diagnosis. Early disease-specific treatment is essential to prevent irreversible disability.

\section{Conflict of Interest}

Dr Flanagan has served on advisory boards for Alexion, Genentech and Horizon Therapeutics. He has received speaker honoraria from Pharmacy Times. He received royalties from UpToDate. Dr Flanagan was a site primary investigator in a randomized clinical trial on inebilizumab in neuromyelitis optica spectrum disorder run by Medimmune/Viela Bio/Horizon Therapeutics. Dr Flanagan has received funding from the NIH (R01NS113828). Dr Flanagan is a member of the medical advisory board of the MOG project. Dr Flanagan is an editorial board member of the Journal of the Neurological Sciences and Neuroimmunology Reports.

\section{References}

1 Flanagan EP, Pittock SJ. Diagnosis and management of spinal cord emergencies. Handb Clin Neurol 2017;140:319-335

2 Dubey D, Pittock SJ, Krecke KN, et al. Clinical, radiologic, and prognostic features of myelitis associated with myelin oligodendrocyte glycoprotein autoantibody. JAMA Neurol 2019;76(03): 301-309

3 Transverse Myelitis Consortium Working Group. Proposed diagnostic criteria and nosology of acute transverse myelitis. Neurology 2002;59(04):499-505

4 Zalewski NL, Flanagan EP, Keegan BM. Evaluation of idiopathic transverse myelitis revealing specific myelopathy diagnoses. Neurology 2018;90(02):e96-e102

5 Ahuja CS, Wilson JR, Nori S, et al. Traumatic spinal cord injury. Nat Rev Dis Primers 2017;3:17018

6 Lee BB, Cripps RA, Fitzharris M, Wing PC. The global map for traumatic spinal cord injury epidemiology: update 2011, global incidence rate. Spinal Cord 2014;52(02):110-116

7 Griffin MR, Opitz JL, Kurland LT, Ebersold MJ, O’Fallon WM. Traumatic spinal cord injury in Olmsted County, Minnesota, 1935-1981. Am J Epidemiol 1985;121(06):884-895

8 Young J, Quinn S, Hurrell M, Taylor B. Clinically isolated acute transverse myelitis: prognostic features and incidence. Mult Scler 2009;15(11):1295-1302

9 Chung KK, Altmann D, Barkhof F, et al. A 30-year clinical and magnetic resonance imaging observational study of multiple sclerosis and clinically isolated syndromes. Ann Neurol 2020;87 (01):63-74 
10 Sechi E, Shosha E, Williams JP, et al. Aquaporin-4 and MOG autoantibody discovery and idiopathic transverse myelitis epidemiology. Neurology 2019;93(04):e414-e420

11 Ptaszynski AE, Hooten WM, Huntoon MA. The incidence of spontaneous epidural abscess in Olmsted County from 1990 through 2000: a rare cause of spinal pain. Pain Med 2007;8(04): 338-343

12 Flanagan EP, Cabre P, Weinshenker BG, et al. Epidemiology of aquaporin-4 autoimmunity and neuromyelitis optica spectrum. Ann Neurol 2016;79(05):775-783

13 Senanayake B, Jitprapaikulsan J, Aravinthan M, et al. Seroprevalence and clinical phenotype of MOG-IgG-associated disorders in Sri Lanka. J Neurol Neurosurg Psychiatry 2019;90(12): $1381-1383$

14 Zalewski NL, Rabinstein AA, Krecke KN, et al. Characteristics of spontaneous spinal cord infarction and proposed diagnostic criteria. JAMA Neurol 2019;76(01):56-63

15 Messacar K, Schreiner TL, Van Haren K, et al. Acute flaccid myelitis: a clinical review of US cases 2012-2015. Ann Neurol 2016;80(03):326-338

16 Suanprasert N, Taylor BV, Klein CJ, et al. Polyneuropathies and chronic inflammatory demyelinating polyradiculoneuropathy in multiple sclerosis. Mult Scler Relat Disord 2019;30:284-290

17 Ropper AE, Ropper AH. Acute spinal cord compression. N Engl J Med 2017;376(14):1358-1369

18 Hedera P. Hereditary myelopathies. Continuum (Minneap Minn) 2018;24(2, Spinal Cord Disorders):523-550

19 Kim SM, Go MJ, Sung JJ, Park KS, Lee KW. Painful tonic spasm in neuromyelitis optica: incidence, diagnostic utility, and clinical characteristics. Arch Neurol 2012;69(08):1026-1031

20 Savoldi F, Nasr Z, Hu W, et al. McArdle sign: a specific sign of multiple sclerosis. Mayo Clin Proc 2019;94(08):1427-1435

21 Sechi E, Krecke KN, Pittock SJ, et al. Frequency and characteristics of MRI-negative myelitis associated with MOG autoantibodies. Mult Scler 2021;27(02):303-308

22 Paul P, McKeon A, Pittock SJ, et al. GFAP IgG associated inflammatory polyneuropathy. J Neuroimmunol 2020;343:577233

23 Vazquez Do Campo R, Stephens A, Marin Collazo IV, Rubin DI. MOG antibodies in combined central and peripheral demyelination syndromes. Neurol Neuroimmunol Neuroinflamm 2018;5 (06):e503

24 Sechi G, Sechi E, Fois C, Kumar N. Advances in clinical determinants and neurological manifestations of B vitamin deficiency in adults. Nutr Rev 2016;74(05):281-300

25 Flanagan EP, Hinson SR, Lennon VA, et al. Glial fibrillary acidic protein immunoglobulin $\mathrm{G}$ as biomarker of autoimmune astrocytopathy: analysis of 102 patients. Ann Neurol 2017;81(02): 298-309

26 Grill MF. Infectious myelopathies. Continuum (Minneap Minn) 2018;24(2, Spinal Cord Disorders):441-473

27 Stern BJ, Royal W III, Gelfand JM, et al. Definition and consensus diagnostic criteria for neurosarcoidosis: from the Neurosarcoidosis Consortium Consensus Group. JAMA Neurol 2018;75(12): 1546-1553

28 Flanagan EP, O'Neill BP, Porter AB, Lanzino G, Haberman TM, Keegan BM. Primary intramedullary spinal cord lymphoma. Neurology 2011;77(08):784-791

29 Sechi E, Addis A, Batzu L, et al. Late presentation of NMOSD as rapidly progressive leukoencephalopathy with atypical clinical and radiological findings. Mult Scler 2018;24(05):685-688

30 Cobo-Calvo A, Ruiz A, Maillart E, et al; OFSEP and NOMADMUS Study Group. Clinical spectrum and prognostic value of CNS MOG autoimmunity in adults: the MOGADOR study. Neurology 2018;90(21):e1858-e1869

31 Shosha E, Dubey D, Palace J, et al. Area postrema syndrome: frequency, criteria, and severity in AQP4-IgG-positive NMOSD. Neurology 2018;91(17):e1642-e1651
32 Uygunoglu U, Zeydan B, Ozguler Y, et al. Myelopathy in Behçet's disease: the Bagel sign. Ann Neurol 2017;82(02):288-298

33 Berkowitz AL, Samuels MA. The neurology of Sjogren's syndrome and the rheumatology of peripheral neuropathy and myelitis. Pract Neurol 2014;14(01):14-22

34 Birnbaum J, Petri M, Thompson R, Izbudak I, Kerr D. Distinct subtypes of myelitis in systemic lupus erythematosus. Arthritis Rheum 2009;60(11):3378-3387

35 Zheng Y, Zhang Y, Cai M, Lai N, Chen Z, Ding M. Central nervous system involvement in ANCA-associated vasculitis: what neurologists need to know. Front Neurol 2019;9:1166

36 Kaufman DM, Kaplan JG, Litman N. Infectious agents in spinal epidural abscesses. Neurology 1980;30(08):844-850

37 Flanagan EP, Kaufmann TJ, Krecke KN, et al. Discriminating long myelitis of neuromyelitis optica from sarcoidosis. Ann Neurol 2016;79(03):437-447

38 Sechi E, Morris PP, McKeon A, et al. Glial fibrillary acidic protein IgG related myelitis: characterisation and comparison with aquaporin-4-IgG myelitis. J Neurol Neurosurg Psychiatry 2019; 90(04):488-490

39 AbdelRazek MA, Mowla A, Farooq S, Silvestri N, Sawyer R, Wolfe G. Fibrocartilaginous embolism: a comprehensive review of an under-studied cause of spinal cord infarction and proposed diagnostic criteria. J Spinal Cord Med 2016;39(02):146-154

40 Di Lazzaro V, Restuccia D, Oliviero A, et al. Ischaemic myelopathy associated with cocaine: clinical, neurophysiological, and neuroradiological features. J Neurol Neurosurg Psychiatry 1997;63 (04):531-533

41 Chang CW, Donovan DJ, Liem LK, et al. Surfers' myelopathy: a case series of 19 novice surfers with nontraumatic myelopathy. Neurology 2012;79(22):2171-2176

42 Decker ML, Emery DJ, Smyth PS, Lu JQ, Lacson A, Yacyshyn E. Microscopic polyangiitis with spinal cord involvement: a case report and review of the literature. J Stroke Cerebrovasc Dis 2016;25(07):1696-1704

43 Galetta SL, Balcer LJ, Lieberman AP, Syed NA, Lee JM, Oberholtzer JC. Refractory giant cell arteritis with spinal cord infarction. Neurology 1997;49(06):1720-1723

44 Sveinsson O, Herrman L, Hietala MA. Heroin-induced acute myelopathy with extreme high levels of CSF glial fibrillar acidic protein indicating a toxic effect on astrocytes. BMJ Case Rep 2017;2017:bcr-2017-219903

45 Mastaglia FL, McCallum RI, Walder DN. Myelopathy associated with decompression sickness: a report of six cases. Clin Exp Neurol 1983;19:54-59

46 Leep Hunderfund AN, Wijdicks EF. Intramedullary spinal cord hemorrhage (hematomyelia). Rev Neurol Dis 2009;6(02):E54-E61

47 Raasck K, Habis AA, Aoude A, et al. Spontaneous spinal epidural hematoma management: a case series and literature review. Spinal Cord Ser Cases 2017;3:16043

48 Sotoca J, Rodríguez-Álvarez Y. COVID-19-associated acute necrotizing myelitis. Neurol Neuroimmunol Neuroinflamm 2020;7 (05):e803

49 Kira J, Kawano Y, Yamasaki K, Tobimatsu S. Acute myelitis with hyperIgEaemia and mite antigen specific IgE: atopic myelitis. J Neurol Neurosurg Psychiatry 1998;64(05):676-679

50 Young WF. Cervical spondylotic myelopathy: a common cause of spinal cord dysfunction in older persons. Am Fam Physician 2000;62(05):1064-1070, 1073

51 Joanes V. Cervical disc herniation presenting with acute myelopathy. Surg Neurol 2000;54(02):198

52 Murphy OC, Salazar-Camelo A, Jimenez JA, et al. Clinical and MRI phenotypes of sarcoidosis-associated myelopathy. Neurol Neuroimmunol Neuroinflamm 2020;7(04):e722

53 Flanagan EP, McKeon A, Lennon VA, et al. Paraneoplastic isolated myelopathy: clinical course and neuroimaging clues. Neurology 2011;76(24):2089-2095 
54 Murphy OC, Hedjoudje A, Salazar-Camelo A, Pardo CA, Gailloud P. Clinical characteristics, misdiagnosis and outcomes of patients with low-flow spinal arteriovenous fistulas. J Neurol Sci 2020; 413:116863

55 Pandey S, Holla VV, Rizvi I, Qavi A, Shukla R. Can vitamin B12 deficiency manifest with acute posterolateral or posterior cord syndrome? Spinal Cord Ser Cases 2016;2:16006

56 Yuan JL, Wang SK, Jiang T, Hu WL. Nitrous oxide induced subacute combined degeneration with longitudinally extensive myelopathy with inverted V-sign on spinal MRI: a case report and literature review. BMC Neurol 2017;17(01):222

57 Huemer M, Scholl-Bürgi S, Hadaya K, et al. Three new cases of late-onset cblC defect and review of the literature illustrating when to consider inborn errors of metabolism beyond infancy. Orphanet J Rare Dis 2014;9:161

58 Girard B, Bonnemains C, Schmitt E, Raffo E, Bilbault C. Biotinidase deficiency mimicking neuromyelitis optica beginning at the age of 4: a treatable disease. Mult Scler 2017;23(01):119-122

59 Graber JJ, Nolan CP. Myelopathies in patients with cancer. Arch Neurol 2010;67(03):298-304

60 Wong CS, Van Dyk J, Milosevic M, Laperriere NJ. Radiation myelopathy following single courses of radiotherapy and retreatment. Int J Radiat Oncol Biol Phys 1994;30(03):575-581

61 Wong CS, Fehlings MG, Sahgal A. Pathobiology of radiation myelopathy and strategies to mitigate injury. Spinal Cord 2015;53(08):574-580

62 Sechi EM, Markovic SN, McKeon A, et al. Neurological autoimmunity and immune checkpoint inhibitors: autoantibody profiles and outcomes. Neurology 2020;95(17):e2442-e2452

63 Bradshaw MJ, Mobley BC, Zwerner JP, Sriram S. Autopsy-proven demyelination associated with infliximab treatment. Neurol Neuroimmunol Neuroinflamm 2016;3(02):e205

64 Kunchok A, Aksamit AJ Jr, Davis JM III, et al. Association between tumor necrosis factor inhibitor exposure and inflammatory central nervous system events. JAMA Neurol 2020;77(08):937-946

65 Cohen DA, Lopez-Chiriboga AS, Pittock SJ, et al. Posttransplant autoimmune encephalitis. Neurol Neuroimmunol Neuroinflamm 2018;5(06):e497

66 Montalva-Iborra A, Alcanyis-Alberola M, Grao-Castellote C, Torralba-Collados F, Giner-Pascual M. Risk factors in iatrogenic spinal cord injury. Spinal Cord 2017;55(09):818-822

67 Gialdini G, Parikh NS, Chatterjee A, et al. Rates of spinal cord infarction after repair of aortic aneurysm or dissection. Stroke 2017;48(08):2073-2077

68 Lapuyade B, Sibon I, Jeanin S, Dousset V. Neurological picture. Spinal cord involvement in posterior reversible encephalopathy syndrome. J Neurol Neurosurg Psychiatry 2009;80(01):35

69 Magaña SM, Matiello M, Pittock SJ, et al. Posterior reversible encephalopathy syndrome in neuromyelitis optica spectrum disorders. Neurology 2009;72(08):712-717

70 Flanagan EP. Autoimmune myelopathies. Handb Clin Neurol 2016;133:327-351

71 Post MJ, Becerra JL, Madsen PW, et al. Acute spinal subdural hematoma: MR and CT findings with pathologic correlates. AJNR Am J Neuroradiol 1994;15(10):1895-1905

72 Song KJ, Choi BW, Kim GH, Kim JR. Clinical usefulness of CTmyelogram comparing with the MRI in degenerative cervical spinal disorders: is CTM still useful for primary diagnostic tool? J Spinal Disord Tech 2009;22(05):353-357

73 Diehn FE, Maus TP, Morris JM, et al. Uncommon manifestations of intervertebral disk pathologic conditions. Radiographics 2016; 36(03):801-823

74 Koeller KK, Rosenblum RS, Morrison AL. Neoplasms of the spinal cord and filum terminale: radiologic-pathologic correlation. Radiographics 2000;20(06):1721-1749

75 Flanagan EP, Krecke KN, Marsh RW, Giannini C, Keegan BM, Weinshenker BG. Specific pattern of gadolinium enhancement in spondylotic myelopathy. Ann Neurol 2014;76(01):54-65
76 Conway BL, Clarke MJ, Kaufmann TJ, Flanagan EP. Utility of extension views in spondylotic myelopathy mimicking transverse myelitis. Mult Scler Relat Disord 2017;11:62-64

77 Asnafi S, Morris PP, Sechi E, et al. The frequency of longitudinally extensive transverse myelitis in MS: a population-based study. Mult Scler Relat Disord 2020;37:101487

78 Filippi M, Preziosa P, Banwell BL, et al. Assessment of lesions on magnetic resonance imaging in multiple sclerosis: practical guidelines. Brain 2019;142(07):1858-1875

79 Lucchinetti CF, Kimmel DW, Lennon VA. Paraneoplastic and oncologic profiles of patients seropositive for type 1 antineuronal nuclear autoantibodies. Neurology 1998;50(03): 652-657

80 Lin CC, Chiu MJ. Teaching Neurolmage: cervical cord atrophy with dorsal root ganglionopathy in Sjögren syndrome. Neurology 2008;70(07):e27

81 Chee CG, Park KS, Lee JW, et al. MRI features of aquaporin-4 antibody-positive longitudinally extensive transverse myelitis: insights into the diagnosis of neuromyelitis optica spectrum disorders. AJNR Am J Neuroradiol 2018;39(04):782-787

82 Yonezu T, Ito S, Mori M, et al. "Bright spotty lesions" on spinal magnetic resonance imaging differentiate neuromyelitis optica from multiple sclerosis. Mult Scler 2014;20(03):331-337

83 Zalewski NL, Morris PP, Weinshenker BG, et al. Ring-enhancing spinal cord lesions in neuromyelitis optica spectrum disorders. J Neurol Neurosurg Psychiatry 2017;88(03):218-225

84 Flanagan EP, Weinshenker BG, Krecke KN, et al. Short myelitis lesions in aquaporin-4-IgG-positive neuromyelitis optica spectrum disorders. JAMA Neurol 2015;72(01):81-87

85 Kitley J, Leite MI, Küker W, et al. Longitudinally extensive transverse myelitis with and without aquaporin 4 antibodies. JAMA Neurol 2013;70(11):1375-1381

86 Zalewski NL, Krecke KN, Weinshenker BG, et al. Central canal enhancement and the trident sign in spinal cord sarcoidosis. Neurology 2016;87(07):743-744

87 Faig J, Busse O, Salbeck R. Vertebral body infarction as a confirmatory sign of spinal cord ischemic stroke: report of three cases and review of the literature. Stroke 1998;29(01):239-243

88 Premkumar A, Marincola F, Taubenberger J, Chow C, Venzon D, Schwartzentruber D. Metastatic melanoma: correlation of MRI characteristics and histopathology. J Magn Reson Imaging 1996; 6(01):190-194

89 Ginat DT, Meyers SP. Intracranial lesions with high signal intensity on T1-weighted MR images: differential diagnosis. Radiographics 2012;32(02):499-516

90 Wiesmann M, Padovan CS, Pfister HW, Yousry TA. Intracranial dural arteriovenous fistula with spinal medullary venous drainage. Eur Radiol 2000;10(10):1606-1609

91 Sechi E, Flanagan EP. Spinal arteriovenous fistula's often misdiagnosed as myelitis; can we stem the flow? J Neurol Sci 2020; 413:116868

92 Zalewski NL, Rabinstein AA, Brinjikji W, et al. Unique gadolinium enhancement pattern in spinal dural arteriovenous fistulas. JAMA Neurol 2018;75(12):1542-1545

93 Rykken JB, Diehn FE, Hunt $\mathrm{CH}$, et al. Rim and flame signs: postgadolinium MRI findings specific for non-CNS intramedullary spinal cord metastases. AJNR Am J Neuroradiol 2013;34(04): 908-915

94 Madhavan AA, Diehn FE, Rykken JB, et al. The central dot sign: a specific post-gadolinium enhancement feature of intramedullary spinal cord metastases. Clin Neuroradiol 2021;31(02): 383-390

95 Savoldi F, Kaufmann TJ, Flanagan EP, Toledano M, Weinshenker BG. Elsberg syndrome: a rarely recognized cause of cauda equina syndrome and lower thoracic myelitis. Neurol Neuroimmunol Neuroinflamm 2017;4(04):e355

96 Burns TM, Mauermann ML. The evaluation of polyneuropathies. Neurology 2011;76(07, Suppl 2):S6-S13 
97 Devinsky O, Cho ES, Petito CK, Price RW. Herpes zoster myelitis. Brain 1991;114(Pt 3):1181-1196

98 Jain KK, Malhotra HS, Garg RK, Gupta PK, Roy B, Gupta RK. Prevalence of MR imaging abnormalities in vitamin B12 deficiency patients presenting with clinical features of subacute combined degeneration of the spinal cord. J Neurol Sci 2014;342 (1-2):162-166

99 Larner AJ, Zeman AZ, Allen CM, Antoun NM. MRI appearances in subacute combined degeneration of the spinal cord due to vitamin B12 deficiency. J Neurol Neurosurg Psychiatry 1997; 62(01):99-100

100 Kumar N, Gross JB Jr, Ahlskog JE. Myelopathy due to copper deficiency. Neurology 2003;61(02):273-274

101 Berlit P, Ringelstein A, Liebig T. Spinal MRI precedes clinical improvement in subacute combined degeneration with B12 deficiency. Neurology 2004;63(03):592

102 Khan M, Ambady P, Kimbrough D, et al. Radiation-induced myelitis: initial and follow-up MRI and clinical features in patients at a single tertiary care institution during 20 years. AJNR Am J Neuroradiol 2018;39(08):1576-1581

103 Kamtchum Tatuene J, Pignel R, Pollak P, Lovblad KO, Kleinschmidt A, Vargas MI. Neuroimaging of diving-related decompression illness: current knowledge and perspectives. AJNR Am J Neuroradiol 2014;35(11):2039-2044

104 Nagel MA, Forghani B, Mahalingam R, et al. The value of detecting anti-VZV IgG antibody in CSF to diagnose VZV vasculopathy. Neurology 2007;68(13):1069-1073

105 van Dop WA, Kersten MJ, de Wever B, Hovius JW. Seronegative Lyme neuroborreliosis in a patient using rituximab. BMJ Case Rep 2013;2013:bcr2012007627

106 Barreras P, Fitzgerald KC, Mealy MA, et al. Clinical biomarkers differentiate myelitis from vascular and other causes of myelopathy. Neurology 2018;90(01):e12-e21

107 Tyler KL, Pape J, Goody RJ, Corkill M, Kleinschmidt-DeMasters BK. CSF findings in 250 patients with serologically confirmed West Nile virus meningitis and encephalitis. Neurology 2006;66(03): 361-365

108 Giovannoni G. Cerebrospinal fluid analysis. Handb Clin Neurol 2014;122:681-702

109 Chow E, Troy SB. The differential diagnosis of hypoglycorrhachia in adult patients. Am J Med Sci 2014;348(03):186-190

110 Seyfert S, Kunzmann V, Schwertfeger N, Koch HC, Faulstich A. Determinants of lumbar CSF protein concentration. J Neurol 2002;249(08):1021-1026

111 Majed M, Fryer JP, McKeon A, Lennon VA, Pittock SJ. Clinical utility of testing AQP4-IgG in CSF: guidance for physicians. Neurol Neuroimmunol Neuroinflamm 2016;3(03):e231

112 Reindl M, Schanda K, Woodhall M, et al. International multicenter examination of MOG antibody assays. Neurol Neuroimmunol Neuroinflamm 2020;7(02):e674

113 Mariotto SGA, Batzu L, Delogu R, et al. Diagnostic relevance of testing MOG-Abs in CSF of seronegative cases. Abstract-5th Congress of the European Academy of Neurology, Philadelphia 2019

114 Waters P, Fadda G, Woodhall M, et al. Serial anti-myelin oligodendrocyte glycoprotein antibody analyses and outcomes in children with demyelinating syndromes. JAMA Neurol 2020;77 (01):82-93

115 Fritz D, van de Beek D, Brouwer MC, Booij J. Whole-body 18F-FDG PET-CT in the diagnosis of neurosarcoidosis. Mayo Clin Proc 2020;95(05):1082-1084

116 Flanagan EP, Hunt $\mathrm{CH}$, Lowe V, et al. [(18)F]-fluorodeoxyglucosepositron emission tomography in patients with active myelopathy. Mayo Clin Proc 2013;88(11):1204-1212

117 Pittock SJ, Kryzer TJ, Lennon VA. Paraneoplastic antibodies coexist and predict cancer, not neurological syndrome. Ann Neurol 2004;56(05):715-719
118 Horta ES, Lennon VA, Lachance DH, et al. Neural autoantibody clusters aid diagnosis of cancer. Clin Cancer Res 2014;20(14): 3862-3869

119 Luetmer PH, Lane JI, Gilbertson JR, Bernstein MA, Huston J III, Atkinson JL. Preangiographic evaluation of spinal dural arteriovenous fistulas with elliptic centric contrast-enhanced MR angiography and effect on radiation dose and volume of iodinated contrast material. AJNR Am J Neuroradiol 2005;26(04):711-718

120 Barreras P, Heck D, Greenberg B, Wolinsky JP, Pardo CA, Gailloud $P$. Analysis of 30 spinal angiograms falsely reported as normal in 18 patients with subsequently documented spinal vascular malformations. AJNR Am J Neuroradiol 2017;38(09):1814-1819

121 Cohen-Gadol AA, Zikel OM, Miller GM, Aksamit AJ, Scheithauer BW, Krauss WE. Spinal cord biopsy: a review of 38 cases. Neurosurgery 2003;52(04):806-815, discussion 815-816

122 Venkatasubramanian C, Lopez GA, O'Phelan KH, Group EW. Emergency neurological life support: fourth edition, updates in the approach to early management of a neurological emergency. Neurocrit Care 2020;32(02):636-640

123 Brophy GM, Human T. Pharmacotherapy pearls for emergency neurological life support. Neurocrit Care 2017;27(Suppl 1):51-73

124 Strohm TA, John S, Hussain MS. Cerebrospinal fluid drainage and blood pressure elevation to treat acute spinal cord infarct. Surg Neurol Int 2018;9:195

125 Robertson CE, Brown RD Jr, Wijdicks EF, Rabinstein AA. Recovery after spinal cord infarcts: long-term outcome in 115 patients. Neurology 2012;78(02):114-121

126 Abboud H, Petrak A, Mealy M, Sasidharan S, Siddique L, Levy M. Treatment of acute relapses in neuromyelitis optica: steroids alone versus steroids plus plasma exchange. Mult Scler 2016;22 (02):185-192

127 Kleiter I, Gahlen A, Borisow N, et al; NEMOS (Neuromyelitis Optica Study Group) Apheresis therapies for NMOSD attacks: a retrospective study of 207 therapeutic interventions. Neurol Neuroimmunol Neuroinflamm 2018;5(06):e504

128 Bonnan M, Valentino R, Debeugny S, et al. Short delay to initiate plasma exchange is the strongest predictor of outcome in severe attacks of NMO spectrum disorders. J Neurol Neurosurg Psychiatry 2018;89(04):346-351

129 Weinshenker BG, O'Brien PC, Petterson TM, et al. A randomized trial of plasma exchange in acute central nervous system inflammatory demyelinating disease. Ann Neurol 1999;46(06): 878-886

130 Elsone L, Panicker J, Mutch K, Boggild M, Appleton R, Jacob A. Role of intravenous immunoglobulin in the treatment of acute relapses of neuromyelitis optica: experience in 10 patients. Mult Scler 2014;20(04):501-504

131 Jarius S, Ruprecht K, Kleiter I, et al; In Cooperation with the Neuromyelitis Optica Study Group (NEMOS) MOG-IgG in NMO and related disorders: a multicenter study of 50 patients. Part 2: epidemiology, clinical presentation, radiological and laboratory features, treatment responses, and long-term outcome. J Neuroinflammation 2016;13(01):280

132 Le Page E, Veillard D, Laplaud DA, et al; COPOUSEP Investigators West Network for Excellence in Neuroscience. Oral versus intravenous high-dose methylprednisolone for treatment of relapses in patients with multiple sclerosis (COPOUSEP): a randomised, controlled, double-blind, non-inferiority trial. Lancet 2015;386 (9997):974-981

133 Jankovic J, Rey Bataillard V, Mercier N, Bonvin C, Michel P. Acute ischemic myelopathy treated with intravenous thrombolysis: four new cases and literature review. Int J Stroke 2019;14(09): 893-897

134 Tahara M, Oeda T, Okada K, et al. Safety and efficacy of rituximab in neuromyelitis optica spectrum disorders (RIN-1 study): a multicentre, randomised, double-blind, placebo-controlled trial. Lancet Neurol 2020;19(04):298-306 
135 Cree BAC, Bennett JL, Kim HJ, et al; N-MOmentum Study Investigators. Inebilizumab for the treatment of neuromyelitis optica spectrum disorder (N-MOmentum): a double-blind, randomised placebo-controlled phase 2/3 trial. Lancet 2019;394(10206): 1352-1363

136 Pittock SJ, Berthele A, Fujihara K, et al. Eculizumab in aquaporin4-positive neuromyelitis optica spectrum disorder. N Engl J Med 2019;381(07):614-625

137 Traboulsee A, Greenberg BM, Bennett JL, et al. Safety and efficacy of satralizumab monotherapy in neuromyelitis optica spectrum disorder: a randomised, double-blind, multicentre, placebocontrolled phase 3 trial. Lancet Neurol 2020;19(05):402-412

138 Jurynczyk M, Messina S, Woodhall MR, et al. Clinical presentation and prognosis in MOG-antibody disease: a UK study. Brain 2017; 140(12):3128-3138

139 Lopez-Chiriboga AS, Sechi E, Buciuc M, et al. Long term outcomes in myelin oligodendrocyte glycoprotein-IgG (MOG-IgG) associated disorders. JAMA Neurol 2020;77(12):1575-1577

140 Li S, Ren H, Xu Y, et al. Long-term efficacy of mycophenolate mofetil in myelin oligodendrocyte glycoprotein antibody-associated disorders: a prospective study. Neurol Neuroimmunol Neuroinflamm 2020;7(03):e705

141 Hacohen Y, Wong YY, Lechner C, et al. Disease course and treatment responses in children with relapsing myelin oligodendrocyte glycoprotein antibody-associated disease. JAMA Neurol 2018;75(04):478-487

142 Durozard P, Rico A, Boutiere C, et al. Comparison of the response to rituximab between myelin oligodendrocyte glycoprotein and aquaporin-4 antibody diseases. Ann Neurol 2020;87(02):256-266

143 Rae-Grant A, Day GS, Marrie RA, et al. Practice guideline recommendations summary: disease-modifying therapies for adults with multiple sclerosis: report of the Guideline Development, Dissemination, and Implementation Subcommittee of the American Academy of Neurology. Neurology 2018;90(17):777-788

144 Dubey D, David WS, Reynolds KL, et al. Severe neurological toxicity of immune checkpoint inhibitors: growing spectrum. Ann Neurol 2020;87(05):659-669

145 Gempp E, Blatteau JE. Risk factors and treatment outcome in scuba divers with spinal cord decompression sickness. J Crit Care 2010;25(02):236-242
146 Albuja AC, Qaiser S, Lightner DD, et al. Surfer's myelopathy without surfing: a report of two pediatric patients. Spinal Cord Ser Cases 2017;3:17008

147 Nakamoto BK, Siu AM, Hashiba KA, et al. Surfer's myelopathy: a radiologic study of 23 cases. AJNR Am J Neuroradiol 2013;34 (12):2393-2398

148 Joseph PJ, Reyes MR. Dorsal column myelopathy following intrathecal chemotherapy for acute lymphoblastic leukemia. J Spinal Cord Med 2014;37(01):107-113

149 Woldeamanuel YW, Hassan A, Zenebe G. Neurolathyrism: two Ethiopian case reports and review of the literature. J Neurol 2012;259(07):1263-1268

150 Siddiqi OK, Kapina M,Kumar R, et al. Konzo outbreak in the Western Province of Zambia. Neurology 2020;94(14):e1495-e1501

151 Brinjikji W, Colombo E, Lanzino G. Clinical and angioarchitectural characteristics of spinal vascular malformations of the cervical spine. J Neurosurg Spine 2020;Jan 17;1-8

152 Hegde AN, Mohan S, Lim CC. CNS cavernous haemangioma: "popcorn" in the brain and spinal cord. Clin Radiol 2012;67 (04):380-388

153 Groen RJ, van Alphen HA. Operative treatment of spontaneous spinal epidural hematomas: a study of the factors determining postoperative outcome. Neurosurgery 1996;39(03):494-508, discussion 508-509

154 Dörflinger-Hejlek E, Kirsch EC, Reiter H, Opravil M, Kaim AH. Diffusion-weighted MR imaging of intramedullary spinal cord abscess. AJNR Am J Neuroradiol 2010;31(09):1651-1652

155 Kikuchi S, Shinpo K, Niino M, Tashiro K. Subacute syphilitic meningomyelitis with characteristic spinal MRI findings. J Neurol 2003;250(01):106-107

156 Stich O, Herpers M, Keil A, et al. JC virus myelitis without cerebral involvement in acute myeloid leukemia. Eur J Neurol 2011;18 (11):e143-e144

157 Revankar SG, Sutton DA, Rinaldi MG. Primary central nervous system phaeohyphomycosis: a review of 101 cases. Clin Infect Dis 2004;38(02):206-216

158 Zhu W, Luo S, Zhu L. Multiple spinal lesions in an immunocompetent young man. JAMA Neurol 2017;74(06):741-742 